\title{
Late Pleistocene lake level history of Lake Mungo, Australia
}

\author{
Timothy T. Barrows* \\ School of Earth, Atmospheric and Life Sciences, University of Wollongong, Australia \\ \& \\ Department of Geography, University of Portsmouth, United Kingdom \\ Kathryn E. Fitzsimmons \\ Research Group for Terrestrial Palaeoclimates, Max Planck Institute for Chemistry, Hahn- \\ Meitner-Weg 1, 55128 Mainz, Germany
}

Stephanie Mills

School of Earth, Atmospheric and Life Sciences

University of Wollongong

Jacqui Tumney

Department of Archaeology and History, La Trobe University, Bundoora VIC 3086, Australia

\section{Daryl Pappin}

Heritage Division, Office of Environment and Heritage, Buronga, Australia

\section{Nicola Stern}

Department of Archaeology and History, La Trobe University, Bundoora VIC 3086, Australia

In press in Quaternary Science Reviews

\section{*Corresponding author's contact details:}

Tim.Barrows@uow.edu.au 


\section{ABSTRACT}

Lake Mungo is a currently dry lake basin in the semi-arid zone of southeastern Australia. The transverse dune system on the downwind side contains a record of human occupation of international importance. It also contains one of the most continuous records of climate change over the last glacial cycle in the Australia desert. In this paper we provide a framework for the interpretation of lake level history from before the arrival of people ( $>41 \mathrm{ka})$ until after the establishment of the pastoral industry in the area. We present 83 optically stimulated luminescence ages from the Lake Mungo lunette. The lake level history is reconstructed from 34 stratigraphic sections along three transects through the lunette. The dating reveals considerable lake level fluctuations through time which occur over a depth range of $\sim 10 \mathrm{~m}$ in the basin. At its height, probably at multiple times before $20 \mathrm{ka}$, the lake held more than $1 \mathrm{~km}^{3}$ of water and at its final level at $\sim 19 \mathrm{ka}$, contained only $0.03 \mathrm{~km}^{3}$. The inception of Lake Mungo appears to have taken place during the mid-Pleistocene between $\sim 256-369 \mathrm{ka}$. During the last glacial cycle, Lake Mungo was almost continuously wetter than present from shortly after $60 \mathrm{ka}$ until $\sim 19 \mathrm{ka}$. The Upper Mungo, Arumpo and Zanci units represent a succession of lake filling and drying events, briefly interspersed by soils. The final Zanci unit does not represent a single high lake phase, but an initial lake filling followed by series of shortlived lake level events within a brief period of a few thousand years. At the conclusion of this event, the lake remained dry until the present day. Four OSL ages from a linear dune upwind of Lake Mungo indicates regional aeolian activity from $\sim 30$ ka until present. Widespread erosion that produces the characteristic topography of the lunette began after the arrival of British pastoralists and traditional aboriginal ways of life overlapped briefly with this erosion. The presence of water in Lake Mungo closely corresponds to periods when regional surface temperature was colder than present during the late Pleistocene. Our new data supports a model 
that decreased evaporation and increased runoff were primarily responsible for increased availability of surface water in the hydrological cycle. 


\section{INTRODUCTION}

Lake Mungo, a lake basin in the semi-arid zone of eastern Australia, contains a valuable record of environmental change and some of the earliest archaeological traces on the continent, including the world's oldest known cremation and ritual ochre burial (Bowler et al., 2003; Bowler et al., 1970; Bowler et al., 1972). Australia's oldest recorded human remains were dated to $41 \pm 4 \mathrm{ka}$ (Olley et al., 2006), representing one of the earliest forays of anatomically modern humans out of Africa. The timing of human arrival in Australia remains highly controversial (Clarkson et al., 2017; O'Connell et al., 2018) as does the impact of the arrival on the megafauna and the environment (Hamm et al., 2016; Miller et al., 2016; Miller et al., 1997). These changes occurred against a backdrop of considerable continental climatic variability over the last 100,000 yr (Reeves et al., 2013; Williams et al., 2009).

Lake Mungo lies within a chain of playas in the Willandra Lake system (Fig. 1 inset). These lakes are presently dry but were formerly fed by overflow of the Willandra Creek, a distributary of the Lachlan River which has its headwaters in the eastern Australian highlands. As a playa, the Lake Mungo floor frequently deflated and the sediment accumulated as an arcuate transverse dune system (lunette sensu (Hills, 1940)) on the downwind, eastern margin. The lunette has preserved an almost continuous record of lake level change during the late Pleistocene (Bowler, 1998). The lake level record is important in the context of the general absence of continuous records of climate change in the arid zone of Australia (Fitzsimmons et al., 2013). The archaeological record accompanying the lake level changes provides an opportunity to study human responses to large-scale environmental changes over long timescales (Stern et al., 2013).

The focus of most previous studies has been the antiquity of the human remains and activity traces, initially entirely using radiocarbon dating (Barbetti and Polach, 1973; Bowler 
et al., 1972; Gillespie, 1997; Gillespie, 1998)). Thermoluminescence (TL) dating subsequently provided a means of directly dating Aboriginal fireplaces and sediment deposition (Adams and Mortlock, 1974; Bell, 1991; Huxtable and Aitken, 1977; Oyston, 1996)). More recently, uranium-series and electron-spin resonance techniques provided a means of directly dating human remains, but these techniques are subject to large errors (Thorne et al., 1999). Increased availability and improved protocols for optically stimulated luminescence (OSL) dating, coupled with the ideal suitability of this technique of aeolian sediments such as those forming the Lake Mungo lunette (e.g. (Fitzsimmons et al., 2010)), has led to better chronologies (Bowler et al., 2003; Fitzsimmons et al., 2014; Olley et al., 2006). This technique provides more reliable luminescence ages than TL and on a much longer timescale than radiocarbon. Optical dating also directly dates sediment deposition, allowing landscape evolution to be dated more directly.

The Willandra Lakes is one of the most intensively dated Quaternary locations in Australia, with more than 200 radiocarbon dates published and more than 100 ages from other techniques such as TL, OSL, uranium series and ESR. However, radiocarbon dating of charcoal is practically limited to about $40 \mathrm{ka}$ because contamination is common in lunette settings (Gillespie, 1997; Gillespie, 1998). Additionally, luminescence ages show a great deal of inconsistency between workers for the same unit, such as those summarised in Bowler (1998). Despite the earlier work, there are still significant spatial and temporal gaps in the stratigraphic record, providing an incomplete environmental history. To help contribute to closing these gaps, we present 83 OSL ages for five locations on the lunette, providing one of the largest chronological datasets for the Australian arid zone. By documenting 34 sediment sections along three transects we reassess the stratigraphy of the lunette, focussing on the eastern margin where the sedimentary record is most complete. Lastly, we combine the dating and stratigraphy to review the chronology of sediment deposition and reconstruct the lake level history in the 
context of regional climate change. The hydrological record provides an opportunity to link the arid zone records with the more numerous records in the wetter margins of temperate eastern Australia and provides a more robust context for studies of human responses to changing environments in the region.

\section{GEOMORPHOLOGY AND SETTING}

Lake Mungo is the second southernmost of five major lakes which formed a terminal lake playa system of the Willandra Creek during dry phases but overflowed to the Murray River through the Prungle lakes during the wettest phases (Fig. 1 inset). The lake represents a shallow kidney-shaped basin cut into sediments deposited within a $\sim 6$ million year old marine incursion (Bowler et al., 2006). Sediments deposited by the Willandra Lakes reflect staggered filling and progressive salinisation of water through evaporation down the system from a sandy lunette at Lake Mulurulu in the north to a gypsum-dominated lunette at Chibnalwood Lakes in the south (Fig. 1; inset; Bowler (1998), Bowler et al., (2012)).

The climate contrast between Lake Mungo and its eastern highland catchment is illustrated through the contrast between the climate stations of nearby Mildura, downstream of where the Lachlan joins the Murray River, and Goulburn at the top of the catchment (Bureau of Meteorology, 2020). Goulburn has a mean summer/winter temperature of $20.0 / 7.2{ }^{\circ} \mathrm{C}$ and Mildura $23.8 / 10.6{ }^{\circ} \mathrm{C}$. Mean annual precipitation at Goulburn is $618 \mathrm{~mm} /$ year and Mildura is half that at $286 \mathrm{~mm} /$ year. Mean evaporation at Goulburn is $1263 \mathrm{~mm} /$ year and Mildura is almost twice that at $2188 \mathrm{~mm} /$ year.

The lunette is composed of sandy sediments interbedded with evaporite-rich deflationary sediments (Bowler, 1976). During high lake levels at Lake Mungo, waves and currents driven by prevailing westerly winds washed sandy sediments to the eastern lake edges, forming beaches and source bordering dunes. During periods of fluctuating low lake levels, 
efflorescence of salts on the exposed lake floors resulted in the formation of clay pellets that were blown into crescentic transverse dunes (lunettes). Thus, beach gravels and sandy dunes reflect periods of persistent high-water levels, and clay-rich sediments reflect low lake conditions and higher salinity. Soils developed during periods of landscape stability, associated with lake dry phases or temporary cut-off in sediment supply, such as from lake filling (Bowler, 1998). Severe erosion since the last lake filling has exposed the internal stratigraphy of the lunette and has provided a means for studying its depositional history.

Inflow into Lake Mungo is a channel in the north that accepted overflow from Lake Leaghur at a sill depth of $\sim 67 \mathrm{~m}$ above sea level (Fig. 2). The lowest point on the Lake Mungo floor is in the southern basin at $61 \mathrm{~m}$. The lunette rises typically $20-40 \mathrm{~m}$ above the lake floor. There are four main shorelines on the margin of Lake Mungo. The earliest and highest at $\sim 74$ $\mathrm{m}$ is a cliff cut into the oldest soils of the lunette. This wave erosion is most likely the result of lake full status $(\sim 71 \mathrm{~m})$ and wave action associated with the long fetch across the lake basin from the west. At levels lower than $71 \mathrm{~m}$, the margins have been significantly modified by the deposition of beach and lunette sediments. Two further high-water marks are present at $\sim 69 \mathrm{~m}$ and $\sim 66 \mathrm{~m}$, stratigraphically formed much closer together in time compared to the earlier shoreline. The $69 \mathrm{~m}$ shoreline is represented by gravel beaches on the western margin, and carbonate tubules on the eastern margin of the lake at the Walls of China (Fig. 1). The $66 \mathrm{~m}$ shoreline is the break in slope at the base of the lunette. A ridge at $64 \mathrm{~m}$ marks the last major shoreline and then a series of regressive shorelines lie below this level to $62 \mathrm{~m}$, representing the last significant water level in the lake.

Figure 2 shows the area of Lake Mungo under the scenarios associated with the four main lake shorelines. The reconstructions were created following similar methods to Barrows et al. (2014) (see Site Selection). Lake area and volume for each scenario are presented in Table 1. At a lake level depth of $11 \mathrm{~m}(72 \mathrm{~m})$, the lake would overflow back into Willandra Creek, 
representing the maximum level the lake can obtain. At this level, a minor new channel forms from the overflow of the north basin of Lake Leaghur (Fig. 2). The lake also overflowed at an early stage south of Joulni into two smaller playas (Fig. 2).

Deflationary sediments associated with the lowest shorelines cover the highest shoreline in most places. Silty dune sediments forming an irregular surface with relief varying by $2 \mathrm{~m}$ cover the modern lake floor. Linear and irregular dune sand sheets border the western margin of Lake Mungo (and encroach over the upper shoreline on the western margin) but do not encroach the youngest shorelines, indicating most of the sand movement was contemporary or pre-dates its formation. The last deposition in the lake consists of filling of small basins or soaks adjacent to base of the lunette (Fig. 1). The modern lunette serves as a catchment for runoff that accumulates in soaks along the margin of the lake floor.

Three stratigraphic units, the Golgol, Mungo and Zanci, were originally recognised and dated by Bowler (1971), Bowler et al. (1972) and Polach et al. (1970). These stratigraphic subdivisions were revised by subdividing the Mungo unit into an Upper and Lower and introducing the Arumpo unit (Bowler, 1998), dividing the lunette into five main units. These units are defined by sedimentology, matching to lake levels, and are usually separated by soils. Here we informally group the units into the Lake Mungo Formation, comprised of five members, otherwise we continue to refer them as "units".

\section{Golgol Member}

The Golgol is the oldest unit and comprises the core of most of the main lunette. At the Palaeomagnetic Site ((Bowler, 1998); Fig 1) dune sands lie at the base with overlying pelletal clays, as an upper and lower pair, indicating a major and prolonged high lake level phase followed by lake drying and deflation of the exposed lake bottom. Significant pedogenesis over the upper few metres of the unit, which would require much more than $\sim 20,000$ years compared 
to the modern soil which has only nodular caliche, has resulted in the formation of thick rhizomorphic calcrete. The period of deposition is not well constrained by dating, but TL and OSL dating indicates an age greater than $100 \mathrm{ka}$ (Bowler and Price, 1998; Fitzsimmons et al., 2014; Oyston, 1996).

\section{Lower Mungo Member}

This unit is composed of lakeshore beach and dune sands and represents the first significant lake-full phase during the last glacial cycle. A soil usually separates the Upper from the Lower Mungo Member. Extensive dating of this unit in association with the oldest human remains places its inception before $55 \mathrm{ka}$ (Bowler et al., 2003), lasting until 39 ka (Fitzsimmons et al., 2015).

\section{Upper Mungo Member}

A pelletal clay unit marks a lake level drop and deflation from the lake floor subsequent to the Lower Mungo high lake level phase. The basal age of this unit is dated at approximately 40 ka with deposition continuing until 35 ka (Bowler, 1998). Bowler et al. (2012) and Fitzsimmons et al. (2015) revised the conclusion of this unit closer to $30 \mathrm{ka}$.

\section{Arumpo Member}

This unit is comprised of alternating sandy and pelletal clay units representing deposition over a substantial period. The variable sediments reflect oscillating lake levels with intermittent lake full conditions interspersed with short deflation periods. Bowler (1998) dated this unit from near 35 to $22 \mathrm{ka}$ and Bowler et al. (2012) placed this unit in a narrower period of 34-24.5 ka or closer to $30 \mathrm{ka}$ ((Bowler et al., 2012) Fig. 12). Lakeshore features correlated within this unit are associated with carbonate deposition, which coats gravel and silcrete outcrops (that served as a stone tool source) on the western margin of the lake. 


\section{Zanci Member}

This is the last Pleistocene unit deposited on the lunette and consists of laminated sandy clays. The unit has a well-developed red-brown earth soil reflecting a long period since deposition ceased. This event is relatively short-lived, placed by Bowler (1998) and Bowler et al. (2012) between $\sim 23 \mathrm{ka}$ and $\sim 19 \mathrm{ka}$.

\section{SITE SELECTION}

Sites for sampling for luminescence dating were initially assessed using aerial photography and a digital elevation model collected for the project. Imagery and LiDAR were collected by Fugro Spatial Analysis (Melbourne) in 2007, including 1:10k unrectified aerial photographs of entire lunette, $1: 10 \mathrm{k}$ georectified aerial photographs of central lunette, $1: 5 \mathrm{k}$ georectified aerial mosaic of lunette along $20 \mathrm{~km}$ of the lunette and $1 \mathrm{~m}$ gridded elevation data for essentially the same area as the 1:5000 images $\left(\sim 26 \mathrm{~km}^{2}\right)$. For the remainder of the Lake Mungo area, a 5 m LiDAR DEM (DFSI Spatial Services, NSW Government) was used to study the geomorphology of the Lake Mungo basin and calculate lake levels (Fig. 1). Lake volume was calculated by creating a triangulated irregular network (TIN) surface from the digital elevation model. The ArcGIS Polygon Volume tool was then used to calculate volume below a given lake level, and surface area. All heights referred to in the text are based on the LiDAR digital elevation model (DEM) with a horizontal datum of GDA94, a vertical datum of AHD71 (local geoid model) in MGA zone 54H.

Four transects across erosional blowouts in the lunette (BLW-1 to 4) were selected for study (Fig. 1), of which three have accompanying detailed archaeological studies (Blowouts 1 (=locality 940691) and 2 (=Locality 966617) (Tumney, 2018) and Blowout 3 (=Locality 969660) (Stern, 2015). A small blowout on the lake floor (BLW-4), was investigated for its potential as an archaeological survey site. In addition, a road cut through a linear dune to the 
west of Lake Mungo (MSH) was also sampled (Fig. 1). The sedimentology at each of the sampling sites was logged. Beds were correlated between sites based on soil stratigraphy and similarity in texture and other physical properties. Prominent soils and marker beds were used to trace the major units laterally, using erosional 'residual' sediment sections in the blowouts. Major units were then sampled for OSL to constrain their age. The number of samples was biased towards the younger sediments to provide a chronostratigraphic context for ongoing archaeological studies and because the oldest units have the best exposure at the Joulni sections (Fig. 1) where considerable dating has already focused (see Bowler et al. (2003)).

\section{Blowout 1 (Locality 940691)}

This is the southernmost site located in the section of the lunette with the highest relief, where the sedimentary units are stacked up to $40 \mathrm{~m}$ thick. BLW1 is to the north of the "Palaeomagnetic Site" studied by Barbetti and Allen (1972) and Bowler and Price (1998) (Fig. 1). Thirty-two OSL ages were determined in 11 sections from a near shore blowout and across the main lunette, with additional sites to the north (BLW1; Table 2; Fig. 3, 4).

\section{Blowout 2 (Locality 966617)}

The northernmost site contrasts with the southernmost because the shape of the basin has resulted in a separation of the older and younger components of the lunette system by $\sim 600$ m (Fig. 1). Twenty-Five OSL ages were determined from seven sections along a transect extending from the younger lunette to the outer edge of the older lunette (BLW2; Table 2; Fig. $5,6)$.

\section{Blowout 3 (Locality 969660)}

This location represents an intermediate site, with a discontinuous outer lunette and a more prominent main lunette $200 \mathrm{~m}$ to the east (Fig 1). Wave erosion from lake highs has benched the Golgol unit, removing some of the older units present at BLW-1. Twenty-two OSL 
ages were determined from 14 sections at the front and back of the lunette (BLW3; Table 2; Fig. 7, 8). Two sites were sampled at the front of the lunette together with sections across the thickest sediments of the main lunette.

\section{Blowout 4 (Locality 950674)}

Stratigraphically the youngest site, this blowout occurs in an isolated dune of the frontal lunette between blowouts 2 and 3 on the lake floor (Fig. 1). Erosion of the dune has created a small catchment that can hold a shallow basin of water after heavy rain. Around the shore of this basin $(63.5 \mathrm{~m})$ is situated many hearths which post-date the widespread erosion of the lunette. Two OSL ages were determined from a pit dug in the adjacent deflated sediments to constrain the timing of the waterhole formation (BLW-4; Table 2; Fig 9).

\section{Linear dune}

Lake Mungo is surrounded by linear dune field and sediment mobilised from these dunes contributed to sediment in the lake, either windblown or through encroachment. The top $2.4 \mathrm{~m}$ of a dune cut by the road to the east of the lake was dated using four OSL ages to investigate the timing of dune construction (MSH; Table 2; Figure 9).

\section{STRATIGRAPHY AND SAMPLING STRATEGY}

\section{Sampling}

Sampling for OSL was undertaken at erosional residuals or gullies where stratigraphy was suitably exposed. Zones of pedogenesis were avoided which were identified by either a red, oxidised zone at the top of the unit, organic staining and the presence of charcoal, loss of sedimentary structure through bioturbation or decalcification and the presence of a $\mathrm{B}_{\mathrm{Ca}}$ horizon. Termites are common in Zanci and Arumpo soils and care was taken to avoid nests and bioturbation (Williams, 2019) by only sampling undisturbed bedding. However, BLW1-01 was 
sampled between nests because of a lack of exposure and this sample gave an anomalously young age. Each sample was collected using a $10 \mathrm{~cm}$ long stainless-steel tube with a diameter of $4 \mathrm{~cm}$ hammered into a cleaned surface. We consider that in all cases that this depth interval records a very brief depositional period, well within measurement uncertainties. Depths and unit thicknesses were surveyed using a total station relative to a survey monument placed on the lake floor in 2007 with a position determined by differential GPS.

\section{OSL methodology}

Samples were opened and processed under low intensity red and yellow-orange light at the luminescence dating laboratory, Research School of Earth Sciences, Australian National University. Only the sediment in the central section of the tubes was processed for dating, to minimise the risk of potential exposure to light during collection.

Sand-sized $(120-210 \mu \mathrm{m})$ quartz was isolated according to published methods (Fitzsimmons et al., 2007) including sieving and density separation in sodium polytungstate solution, digestion in dilute hydrochloric acid, hydrogen peroxide and hydrofluoric acid. The resulting clean quartz grains were then mounted onto the central $1 \mathrm{~mm}$ of $10 \mathrm{~mm}$ diameter stainless steel discs using silicone oil; 18 aliquots were prepared from each sample for equivalent dose $\left(D_{e}\right)$ measurement.

Equivalent dose measurements were undertaken using automated Risø TL-DA-12 and TL-DA-15 readers equipped with blue light-emitting diodes for light stimulation and calibrated ${ }^{90} \mathrm{Sr} /{ }^{90} \mathrm{Y}$ beta sources for irradiation (Bøtter-Jensen et al., 2000). Luminescence signals were detected by EMI 9235QA photomultiplier tubes with coated Hoya U-340 filters (Bøtter-Jensen, 1997). Samples were measured using the single-aliquot regenerative-dose (SAR) protocol (Murray and Wintle, 2000; Murray and Wintle, 2003), incorporating an infrared stimulated luminescence (IRSL) wash prior to each OSL signal measurement (Murray and Wintle, 2003). 
Following a preheat plateau test on sample BLW1-1 (Suppl. Fig. 1A), a preheat of $260^{\circ} \mathrm{C}$ and cutheat of $220^{\circ} \mathrm{C}$ for $10 \mathrm{~s}$ was used for all samples. In most instances, the sample aliquots yielded Gaussian distributions, indicating complete bleaching of the signal, and therefore the Central Age Model of (Galbraith et al., 1999) was used to calculate the equivalent dose for those samples). Supplementary Table 1 lists the samples for which "over-dispersion" was observed and shows where the Minimum Age Model was most appropriate in preference to the Central Age Model.

\section{Dose rates}

Environmental radiation dose rates from the quartz-rich sands of Lake Mungo lunette sediments are typically very low (Table 2), yielding attenuated values on the order of $0.5-1.0$ Gy/ka with the exception of the laminated clay-bearing units (such as the Upper Mungo) which yield total dose rates at least twice as great. This characteristic can often result in relatively wide dose distributions due to dose rate heterogeneity (Lomax et al., 2007), and the cosmic ray component of the dose rate can be a significant proportion of the total dose rate (Burrough et al., 2007; Telfer et al., 2017). This means care must be taken to use realistic burial depths for the samples. In situ gamma spectrometry was conducted at all sites in the same sample holes using a portable sodium iodide gamma spectrometer with a three-inch crystal detector. Counting was undertaken for 30 minutes per sample.

Sediment collected from around the sample holes was homogenised, split, and subsampled for elemental analyses in order to calculate beta dose rates. Subsamples were ground in a ball mill and analysed using induction-coupled plasma mass spectrometry (ICPMS) for $U$ and Th, and induction-coupled plasma atomic emission spectrometry (ICP-AES) for K, undertaken at Genalysis Laboratories, Perth, Western Australia. These concentrations were converted to dose rates using the factors of (Adamiec and Aitken, 1998), incorporating 
the moisture content to account for dose rate attenuation (Mejdahl, 1979). The external dose rate for MSH and BLW1-20 to BLW1-24 are derived from radioisotope concentrations. The doses for all other samples are calculated from the gamma spectrometry.

In-situ moisture content of some samples was calculated by weighing the raw and ovendried weight of material from the ends of the tubes, averaged with the moisture content from samples containing the surrounding sediment. Because erosion has dramatically increased drainage, exposed sections were much drier than experienced during most of their buried history. Water contents were therefore corrected by relating that of exposed sections with deeply buried samples of the same sediment type, characterised by grain size and trace element content. All samples had a water content of 3-5\%, except BLW2-09 (10\%) and BLW1-06 $(15 \%)$.

The cosmic ray component of the dose rate was calculated based on sample latitude, longitude, altitude and depth, and assuming a sediment overburden density of $1.9 \mathrm{~g} . \mathrm{cm}^{3}$, using published equations (Prescott and Hutton, 1994). Due to the widespread deflation of the lunette, some sites were formerly buried up to $5 \mathrm{~m}$ below the surface, resulting in an overestimate of cosmic ray dose if the modern depth is used. To improve the accuracy of the cosmic ray dosage, original burial depth was estimated by trigonometry using survey points on the surface of the soil on adjacent residuals. Where the soil was partially eroded, total soil depth was estimated by measuring the depth from the soil surface to the $\mathrm{B}_{\mathrm{Ca}}$ horizon on adjacent residuals. This depth correction may slightly underestimate the cosmic ray dose where there were large gaps in time between the deposition of the dated sediment and that of subsequent sediment cover. Based on the dating results, erosion was very recent and therefore the increase in cosmic ray dose since exposure is negligible. 
All OSL ages in the text are reported in thousands of years $(\mathrm{ka})$ with $1 \sigma$ uncertainty and are relative to the processing date $(2008 \mathrm{CE})$. Where radiocarbon dates have been referred to in the text, they have been calibrated to calendar years using the SHCal13 calibration (Hogg et al., 2013; Reimer et al., 2013) in conjunction with CALIB7.0 (Stuiver and Reimer, 1993) without any reservoir effect on biogenic carbonates (Gillespie et al., 2009). Radiocarbon dates are expressed as radiocarbon years $\left({ }^{14} \mathrm{C}\right.$ yr BP) and calibrated dates as calibrated years (cal yr $\mathrm{BP})$.

\section{Bayesian statistics}

Age inversions are often observed in luminescence chronologies derived from rapidly accumulated sand deposits with very low dose rates (e.g., Bowler (1998)). Age inversions can be interrogated, and chronological precision improved, using Bayesian statistical analyses. The Bayesian approach takes into account the probability distributions of the ages and prior knowledge such as stratigraphic information (ie. a sample stratigraphically above another must be younger).

We conducted a Bayesian analysis for the three best represented stratigraphic units using OxCal (Bronk Ramsey, 2009). Where possible, ages with poor agreement $(\mathrm{A}<60 \%)$ with the rest of the sequences were iteratively removed until the overall agreement index (Ac) was $\sim>60 \%$. Where an age with poor agreement was excluded from the analysis, a percentage chance that the sample should be in this position in the sequence was calculated (in brackets in the following). For the Zanci unit, we used BLW1 S1 (minus BLW1-01, 5.8\%; BLW1-02, 0\%), BLW2 S3 and S2 (which were averaged) and BLW3 S1+2, S4+S5 (minus BLW3-03, 0\%) and S6-S8. For the Arumpo unit, we used BLW1 S2-S7 (minus BLW1-11, 0.0\%; BLW1-33, 0\%; BLW-35, 0.1\%) and BLW2 S6+S4. BLW3 was excluded because soils were not present. For the Upper Mungo unit we only used BLW1 S2-S7 with duplicates of BLW1-18 and 19 
combined. At the same time, we calculated the likely boundary ages for each sampled sequence. These boundary ages provide a good indication of the duration of deposition where samples were taken close to the beginning and end of unit. The estimation of boundary ages relies heavily on the assumption that the distribution of the ages is representative of the unit and the full age range is covered. For our sites, this is likely in most cases where we have multiple ages and because sedimentation rates are high. Lastly, the interval between depositional periods and its uncertainty was also estimated at the same time from the boundaries. Only BLW1 S2-S7 was used to calculate this for the Zanci and Upper Mungo units. Examples of plots showing prior and posterior distributions, together with boundary age estimates, are given in the supplementary information (Suppl. Figures 3a-b, 4). Normalised chi-squared tests $\left(\mathrm{X}^{2} / v\right)$ were conducted to assess the appropriateness of averaging multiple sections together. A value close to unity indicates a single population where scatter in the data can be accounted for solely by random error. Where $X^{2} / v>>1$, the average contains unexpected scatter and where $X^{2} / v<<1$, the average is unexpectedly precise. Unless otherwise noted, means are error-weighted, and the uncertainty is the larger of the internal or external error on the mean.

\section{RESULTS}

Ages calculated for the OSL samples are presented in Table 2. Table 3 presents the results of the Bayesian analysis and gives the likely unit ages, durations and interval lengths together with the respective uncertainties for the younger three units. The OSL behaviour of the samples from Lake Mungo indicate that these sediments are generally well suited to OSL dating using the SAR protocol (see supplementary information). All samples exhibit bright OSL signals with rapid decay indicative of sensitive quartz which is dominated by the fast component and contains negligible feldspar (Suppl. Fig. 1B). The high sensitivity of these 
samples has been attributed to sensitisation through multiple cycles of reworking within the Quaternary sedimentary system (Pietsch et al., 2008). IRSL signals, measured prior to the OSL signal in order to identify potential contamination by feldspar (Murray and Wintle 2003), are low to non-existent. Thermal transfer is generally $<2 \%$, with exception of several very young samples, and recycling values were all within $10 \%$ of unity. Most samples yield dose response characteristics corresponding to a simple exponential function (Suppl. Fig. 1C), with the exception of BLW1-06 from the Golgol unit, which was saturated with respect to the quartz OSL signal.

\section{Stratigraphy}

\section{Golgol Member}

This unit was present at all three sites along the main lunette as the basal unit. This is the thickest unit at the sampled locations, at least $12 \mathrm{~m}$ thick at BLW-1 and displays varying degrees of pedogenesis. At both BLW-1 and 2, where it is made more resistant by calcrete, it is benched by an undated high lake phase. At BLW-2, caliche is up to $3 \mathrm{~m}$ thick, in comparison to the Post-Zanci soil which is typically $30-70 \mathrm{~cm}$ thick and contains carbonate nodules at the base up to about $1 \mathrm{~cm}$ in diameter. Below the pedogenic zone, the unit consists of well-sorted light brown sand with shell fragments. This fore-dune facies represents a relatively high lake level given its coarse sediment and elevation. The two ages for the top and bottom of the unit differ by more than $100 \mathrm{ka}(256 \pm 14 \mathrm{ka}$ and $369 \pm 27 \mathrm{ka})$ despite there being no obvious stratigraphic break. This most likely reflects variation in dose rate measurements in this very low dose rate environment, since the equivalent doses of the two samples are comparable (Suppl. Fig. 2) whereas the calculated dose rates are 25\% different from one another (c. 0.4 vs. 0.55 Gy/ka; Table 2). 
Where exposed at the thickest part of the lunette (BLW-1) the Golgol consists of two units with pedogenesis to several metres thickness. Previous TL ages in this section are younger than the new ages, the lower unit having two ages of $113 \pm 13 \mathrm{ka}$ and $126 \pm 16 \mathrm{ka}$ and the upper unit dated at $98 \pm 30 \mathrm{ka}$ and $99 \pm 17 \mathrm{ka}$ (Bowler and Price, 1998). In other sections of the lunette, Oyston (1996) dated a unit at Joulni under the Lower Mungo that may be correlative and is also younger at $144 \pm 15$ to $178 \pm 29 \mathrm{ka}$ (J4 and J5). Finally, Fitzsimmons et al. (2014) dated one section between BLW1 and 3 at $141 \pm 35 \mathrm{ka}$.

\section{Lower Mungo Member}

This unit consists of a thin, discontinuous sand sheet that can be traced laterally stratigraphically on top of, and behind, the wave-cut cliff in the Golgol unit. The sand is reddish, light brown or pink depending on the erosional source material, sourced from thick, well-developed soils, beach sands or a mixture respectively. An incomplete soil profile at our sites, combined with the incorporation of eroded soils, makes it difficult to determine the length of time of pedogenesis relative to the other units. At BLW-1 there are two ages from one unit of $75.3 \pm 4.2$ and $97.5 \pm 5.0 \mathrm{ka}$, with the variation probably due to dose rate measurments. A single large macropod skull was found at the top of the Lower Mungo at BLW-1, but no other large vertebrate fossils were found at any site in this study. Further north, the unit shows poor outcrop and is not present at BLW-2. At BLW-3, the unit is dated to 38.6 $\pm 2.1 \mathrm{ka}$ (BLW3-16). The unit is continuously exposed at the north end of the Tourist Site (Fig. 1) where it is dated at $39.0 \pm 3.2$ to $51.1 \pm 2.7$ (Fitzsimmons et al., 2014).

Extensive hearths at BLW-1 in the Lower Mungo unit provide minimum limiting ages for its formation. This zone is a shallow soil containing reworked and rounded nodules of calcrete from the Golgol underneath. Also present are rare rounded cobbles of silcrete, often reddish in colour, which cannot be in situ because of their elevation $(>81 \mathrm{~m})$. These are 
probably emu or Genyornis gastroliths, the latter have been recorded up to $400 \mathrm{~g}$ in weight by (Stirling and Zeitz, 1900). The sediment overlying the Golgol unit has an age of $130 \pm 10 \mathrm{ka}$ (BLW1-27; Fig. 3) but is highly likely to be a mixed age sample. Overlying the Golgol soil is a grey soil with no sedimentary structure, probably reworked by human activity, containing abundant hearths on its surface. A single OSL age at the base of $54.3 \pm 3.1$ ka represents a minimum age for this unit in the area sampled. This soil correlates with the ash-rich zone identified by Barbetti and Allen (1972) on the nearby Palaeomagnetic Site. The OSL age is older than the radiocarbon ages on charcoal from hearths at the top of the unit which range from $31,340 \pm 250$ (ANU-682) to $34,700 \pm 480$ cal yr BP (ANU-680) (Barbetti and Allen, 1972). Thermoluminescence dating was applied to baked oven stones at the same site which ranged between 29.5-38.6 ka, with one younger outlier (Huxtable and Aitken, 1977). Bell (1991) reinvestigated the site by dating baked sediment at the same fireplaces and obtained TL ages of $31.4 \pm 2.1$ to $36.4 \pm 2.5 \mathrm{ka}$. The sediment itself had depositional TL ages of $29.3 \pm 3.2$ $\mathrm{ka}$ (Readhead, 1988) and $16.4 \pm 1.2 \mathrm{ka}$ (Bowler and Price, 1998). The radiocarbon ages and the TL ages scatter beyond expected for a single unit. These ages together with the new OSL ages above may indicate a long period of exposure on this section of the Lower Mungo unit on the lunette. Subsequently, the Arumpo unit was deposited at the Palaeomagnetic Site (see next section) with a hearth near the base dated at 30,460 \pm 300 cal yr BP (ANU-667) (Barbetti and Allen, 1972).

In contrast to the south-eastern margin, the Lower Mungo unit is well exposed at Joulni where the burial sites of Mungo I and III are located. Initial TL dating indicated an age of 43.3 \pm 3.8/43.1 $\pm 6.7 \mathrm{ka}(\mathrm{J} 3)$ (Oyston, 1996). Bowler and Price (1998) obtained a statistically identical age of $41.4 \pm 6.7 \mathrm{ka}$ (W1799) on the same section. At the Mungo I burial site, ages in the Lower Mungo unit range from $\sim 48 \mathrm{ka}$ at the top of an augur hole to $\sim 51 \mathrm{ka}$ at the base with large errors, assuming cosmic ray doses decreasing with depth (Bowler and Price, 1998). 
Thorne et al. (1999) subsequently applied OSL dating at a site east of the burials on sediments correlated with the site of the burials and obtained ages of $59 \pm 3 \mathrm{ka}$ and $63 \pm 3 \mathrm{ka}$. These are significantly older than the previously reported ages but are consistent with subsequent extensive dating of the unit by Bowler et al. (2003). These authors found an age range of 62.2 \pm 1.8 to $41.8 \pm 2.4 \mathrm{ka}$. The presence of six soils and three distinct gravel bands indicating high lake phases indicates this unit was deposited over a substantial period. These ages indicate that the Lower Mungo lake level high was a major regional event which lasted at least $20 \mathrm{ka}$.

\section{Upper Mungo Member}

This unit is not a major unit at the three sites investigated. At BLW-1 this unit conformably overlies the Lower Mungo and about $1 \mathrm{~m}$ thick (Fig. 3). It is a pelletal clay sediment, almost entirely clay at the base of unit but grades to sand rich with shell fragments at the top. The clay unit has an age of 37.2 $\pm 2.4 / 41.2 \pm 3.2 \mathrm{ka}$ (BLW1-19) at the base and 37.9 ka (BLW1-18; a duplicate has an anomalous De) at the top of the clay rich unit, indicating it could have been deposited in a short period of time. There are 2 weakly developed soils in this unit and a well-developed soil (40 cm thick) at the top. Three ages in the overlying sand-rich sub-units overlap at their $1 \sigma$ errors and range from 34.5 to $36.7 \mathrm{ka}$. The unit is not present at BLW-2 and the thin outcrop at BLW-3 (Fig. 7) was not dated.

At the Palaeomagnetic Site TL ages of $24.5 \pm 3.7$ (MWC3) and 29.3 $\pm 3.2(\mathrm{MCW} 4)$ (Readhead, 1988) for the Upper Mungo are much younger than our ages for this unit. Given that the thickness of the unit in that paper is around $3 \mathrm{~m}$ compared to the thin deposit we observed, it is possible that Arumpo aged sediments were inadvertently sampled. Further north, the upper boundary of the unit lies above a fish hearth at the Tourist Site which was dated at $38,860+1390 /-1270$ cal yr BP (ANU-2964) (Clark in (Johnston and Clark, 1998) and (Bowler, 1998). Another hearth dated at the level of the Lower Mungo soil (ANU-687) provides a 
maximum age 39,650+1720/-1250 cal yr BP for the Upper Mungo (Barbetti and Polach, 1973). Both radiocarbon ages are consistent with the inception of the unit as dated here $(37.1 \pm 1.7$ $\mathrm{ka})$

In the south, the equivalent of the Upper Mungo unit at the Joulni burial site was dated using TL at 24.6 $\pm 2.4 / 34.0 \pm 3.9 \mathrm{ka}$ (Oyston, 1996). The former selective bleach age being much younger than the total bleach age or the ages here. Bowler and Price (1998) re-dated this unit to $29.3 \pm 3.1 \mathrm{ka}$ (W1798). Bowler et al. (2003) subsequently also re-dated the unit with ages of $37.8 \pm 1.9$ to $42.0 \pm 1.7 \mathrm{ka}$. A third single age of $30.6 \pm 1.1$ near the top was used to put an upper limit of $30 \mathrm{ka}$ on the unit (Bowler et al., 2003), which is 4000 years younger than the dated end of this unit (33.9 ka), which was followed by a hiatus of at least 1000 years.

\section{Arumpo Member}

Arumpo sediments conformably overlie the Upper Mungo surface or lie on an erosional surface of either of the older two units. The unit is present at the surface of the main lunette at BLW-1, and the eastern sections of the lunette at BLW-2 and 3 (Fig. 6, 8). A diverse sedimentology is displayed within this unit representing a dynamic range of lake level conditions over a considerable period. The unit consists of sand, laminated clayey sands and sandy clay, with interbedded clay units. At all sites the deflated sediments are dissociated from shoreline sediments leaving no clear link with lake level height. The maximum number of layers occur at BLW-1 where 2 minor soils and 3 pedogenic zones indicating age gaps in deposition of sediment. None of the soils are as well developed as the soil on the Upper Mungo. The unit ranges in age from $32.8 \pm 0.5$ to $24.1 \pm 1.1 \mathrm{ka}$ at the top of the lunette with some age inversions. At the Palaeomagnetic site, a previous age of $30460+350 /-260$ cal yr BP (ANU667) constraining the start of sedimentation (Barbetti and Polach, 1973) is consistent with this interval. 
This long period of fluctuating lake level included numerous periods of high lake level of long enough duration for mussels and fish to establish in the lake. At BLW-1 there are least 6 major lake drying phases recorded by clay units like the Upper Mungo, 4 of these concentrated into the final depositional phase (Fig. 3, S2). Only one unit is exposed at BLW-3 and none at BLW-2 indicating considerable heterogeneity in sediment deposition along the lunette. Quartz-rich dunes were deposited over the main lunette at all locations during intermittent high lake levels. At the back of the main lunette at BLW-2, there is a thick unit of rhythmically deposited pelletal clay layers where individual layers are 1-2 mm thick. Therefore a $1 \mathrm{~m}$ section may be composed of 500-1000 cycles. The large number of cycles and the preservation indicates rapid filling and drying of the lake over a few years at most.

This unit is correlated with a well-defined shoreline along the front of the lunette associated with precipitation of microbialites (similar to microbialites in southern Victoria; (Last and Last, 2015)) and tubular carbonate (Bowler, 1998). Direct radiocarbon ages on tubules places growth at $26150+400 /-420(\mathrm{~N}-1660)$ to $27490+530 /-510$ cal yr BP (ANU-310) (Polach et al., 1970; Yamasaki et al., 1977).

Although this is a major depositional unit, there are relatively few ages from elsewhere. At Joulni, Oyston (1996) dated a unit at 19.5 $\pm 2.3 / 31.6 \pm 4.0 \mathrm{ka}(\mathrm{J} 1)$ remapped by Bowler and Price (1998) as the Arumpo unit. The range of ages from selective to total bleach bracket most of the ages presented here. Bowler and Price (1998) obtained an age of $22.4 \pm 2.1 \mathrm{ka}$ (W1800) at the younger end of our ages. Subsequent dating by Bowler et al. (2003) at that site suggests the unit began deposition shortly after $30.3 \pm 1.0 \mathrm{ka}$ (M3T $73.3 \mathrm{~m}$ ), consistent with our dated interval. 


\section{Zanci Member}

This unit comprises the front section of the lunette at BLW-1 and the lake-ward parts of the lunette complex at BLW-2 and 3 (Fig. 3-8) whereas BLW-4 is entirely eroded from the Zanci unit. The most pronounced feature in the deposition of this unit is a change in lake geometry due to a decrease in lake volume (Fig. 2). The result was that most of the deflated sediment is in a series of discontinuous clay dunes along the shore-face (Fig. 1). Similar to the Arumpo unit, there is considerable heterogeneity in sediment deposition along the lunette, with areas of $6 \mathrm{~m}$ sand dunes adjacent to sediment-free areas such as at BLW-3 (Fig. 8). The greatest separation of the clay dunes from the main lunette at our sites occurs in the north at BLW-2 at $600 \mathrm{~m}$, due to the low slope angle of the lake basin, which reduces south to $200 \mathrm{~m}$ at BLW-3. At BLW-3, the inner lunette is irregular with the presence of an embayment and the Zanci unit is also deposited on the main lunette. However, the altitude of the Zanci dunes varies between the three localities. The highest site is at BLW-3 where the dune is situated at the top of the break in slope above $75 \mathrm{~m}$, to the north and south, the dune is at the bottom of the break of slope at $65.5 \mathrm{~m}$ and $67.5 \mathrm{~m}$ at BLW-2 and BLW-1 respectively. No depositional shoreline is exposed at any of the sites, but the lowest elevation of these deposits indicates that the lake had only $3.5 \mathrm{~m}$ water in it when it finally emptied. At BLW-1 and 3, the base of the dune is located on a Golgol soil, dated at the former site at $>100 \mathrm{ka}$. Despite the difference in elevation of the central lunette location, the three sites all have similar ages and indicate that this final lake level phase was brief $(23.4 \pm 2.8 \mathrm{ka}$ to $19.8 \pm 1.7 \mathrm{ka})$, lasting only a few thousand years $(3.5 \pm 3.9$ $\mathrm{ka})$.

At all three localities, the facies is similar representing a sandy beach or fore-dune succeeded by a clay dune and sandy pelletal clay units. The most detail is recorded at BLW-2. Two clay lenses indicate deposition of clay dunes during drying phases alternating with fore dune quartz sands. At BLW-3 two clay layers are preserved in the thickest dune section (section 
2). At BLW-1, the sequence is split between the clay dune at the front and a capping on the main lunette (Fig. 3).

This unit correlates with the lowest shoreline mapped by Bowler (1998) at the front of the Tourist Site. As the unit with the best exposure and the last deposited, it has been the focus of a relatively large amount of dating. The best constraints on its formation are supplied by radiocarbon ages on fish otoliths dated by Kalish et al. (1997) and by Long et al. (2014). These ages range from $19370+200 /-200 \mathrm{cal}$ yr BP (OZB-623) to $20450+160 /-170 \mathrm{cal}$ yr BP (OZB$626)$ and $19340+140 /-130$ cal yr BP (SANU-8817) to $21100+170 /-170$ cal yr BP (SANU8814 ) respectively. One anomalous age of $13630+80 /-60$ cal yr BP (SANU-27810) was found at a stratigraphically lower level (Long et al., 2014). The final phase of drying is possibly recorded by unionid shells in growth position from the Lake Mungo lakebed (17580 +370/-370 cal yr BP; N-1656) (Gillespie, 1997; Yamasaki et al., 1977) but this is younger than all other ages here. The Zanci unit has a well-developed soil indicating a considerable lapse of time consistent with the final ages of deposition $(\sim 19 \mathrm{ka})$. There is no significant difference between the soils developed on the Zanci or on uncovered Arumpo sediments. Elsewhere, Fitzsimmons et al. (2014) and Fitzsimmons et al. (2015) did not separate the Zanci and Arumpo where there was no soil separating them. They refer to these laterally equivalent sediments dated from $25-$ $14 \mathrm{ka}$ as Unit E. Sediments at the border of their Upper Mungo/Arumpo boundary at $\sim 23-25$ ka are referred to as the Red Lunette Unit by Fitzsimmons et al. (2014).

\section{Walls Member}

A new unit is proposed here, which is the youngest unit at Lake Mungo, to accommodate the large-scale remobilisation and re-deposition of sediment associated with erosion of the lunette. The unit is named after the 'Walls tank' waterhole which derives its name from the adjacent 'Walls of China' Tourist site (Fig. 1), an area of extensive erosion. The 
unit consists of slope wash units on the flanks on the lunette, alluvial fans at the front of the lunette, extensive mobile dunes at the rear of the lunette and low "coppice" dunes on the lake floor and near the tops of the lunette. The unit has no association with lake deposits and is entirely deposited after the final lake drying and deposition of the Zanci Unit. In Fitzsimmons et al. (2014) these sediments are referred to as Unit F (aeolian) and Unit G (alluvial).

The origin of the Walls unit can be determined from its association with the Zanci soil at the three transects. The Zanci soil is sandy and friable once decalcified and where carbonate has leached to the $\mathrm{B}_{\mathrm{Ca}}$ horizon. The Zanci soil has been eroded over almost the entire lunette, frequently to the $\mathrm{B}_{\mathrm{Ca}}$ which forms a resistant layer. The Walls unit frequently begins as steeply dipping reddish slope wash layers on the front and back of the lunette, deposited over the soil downslope (e.g. Fig 3; section 10; Fig 7. Section 13). The unit forms alluvial fans at the front of the lunette out onto the lake floor (e.g. Fig 5; section 1,2). The sediment lightens to pink as the mixture of reworked soil decreases with dilution of white sand from subsoil sandy clays. The soil is eroded as planar reddish sands at front and back of the lunette, decreasing in a mix of blowout and wash sands until pure white sand from blowout. In places the unit has been stabilised by vegetation and moss/lichen cover as sediment supply has decreased. At BLW3, dunes that formed during the 1980s are now stabilised. The alluvial fan sands are often covered with fine silt stabilised as a coppice dune (e.g. Fig 5; section 2,4)). Finally, some coppice dunes (mostly silt-fine sand) are stabilising the surface and thick sand sheets are being incised and gullied. At the rear of the lunette, an extensive series of dunes remains mobile, consisting of sand winnowed from eroded sediments on the lunette and deflated to the lee of the lunette. The mobile dune field is up to $200 \mathrm{~m}$ wide and encroaches on the hinterland. This unit is actively forming and up to $6 \mathrm{~m}$ of dunes have been deposited at the back of the lunette in the time between the two DEMs used in this paper being collected. 
The Walls unit is much younger than the Pleistocene units above and has an active depositional surface. At BLW1 at the back of the lunette (Fig. 3), slope-wash sands overlying the Zanci soil date to $250 \pm 20 \mathrm{yr}$ and the base of the overlying coppice dune is $100 \pm 20 \mathrm{yr}$ (Fig. 3). At BLW-2 on the alluvial fan at the front of the inner lunette, the sand sheet ranges in age from $140 \pm 10$ to $100 \pm 10 \mathrm{yr}$ and the base of the coppice dune at the front of the inner lunette is $70 \pm 10 \mathrm{yr}$ (Fig. 5). At BLW3 at the rear of the main lunette there is a well-defined contact between erosion of the lunette and the dunefield behind. At the base of the reworked sediments is dated at $260 \pm 40 \mathrm{yr}$ (Fig. 7). A short distance away along the contact with the Zanci soil, a fully intact sheep skeleton was found eroding out on top of the soil.

It is important to note that the scale of modern erosion of the lunette is unparalleled in the last 40,000 years. Relict cliffing and gullying are present on the Golgol unit, but there is no equivalent to the mobile dune exposed in the lunette. Significant erosion was only recorded at one site within the lunette sediments. Below the soil at BLW-3, reworked sediments eroding from the Arumpo unit are rich in charcoal hearths and date to $12.7 \pm 1.0 \mathrm{ka}$ (Fig. 7, S14), but this erosion was limited when it occurred and subsequently stabilised. Given the age of the reworked sediments of the Walls unit, the widespread erosion is most likely a result of pastoral practises after the arrival of British settlers to the area in the 1860 's to 1870 's and the arrival of rabbits in the last 150 years. The ages are consistent with the clear association of the sheep skeleton with the soil contact. The young age is supported by the high observed rates of erosion (e.g., $60 \mathrm{~cm}$ in 25 years in Bowler and Magee (2000), and also the absence of soil developed on depositional surfaces.

\section{Linear dunes}

A linear dunefield extends up to the western shore of the lake and is eroded by the lowest shoreline, indicating that it pre-dates, or is at least contemporary with the Zanci lake 
level high. North of the visitors centre, dunes cover the higher shorelines indicating they postdate the Arumpo high lake levels (Fig. 1). The basal date for the linear dune above the highest shoreline was $30 \pm 1.9 \mathrm{ka}$. Above this level, the dune sand is mixed showing continuous redeposition from $21 \pm 2.6$ through to $2.6 \pm 0.3 \mathrm{ka}$. The crests of the dunes are currently active and reworked sand overlies a soil on the dune which presumably is pre-British colonisation in age (Fig. 9, S1). In a similar setting, Readhead (1988) found ages ranging from $6.9 \pm 2.3$ (MASH2) to $41.5 \pm 4.4$ (MASH6) in a longitudinal sand dune to the west of the lake. The unexpected linear age trend in the section is suggestive of reworking by wind or biological agents.

\section{Facies model}

Regardless of the age, the sediments in the Lake Mungo lunette display a recurring depositional pattern related to sediment supply as a function of lake level. The pattern is best typified in sections BLW1-S1 and BLW2-S3 and 4. Elements from these sites are used to construct a facies model (Fig. 10). This model is used to interpret the stratigraphy of the lunette to construct a lake level history.

The base of the model lies on a soil (Fig. 10). A well-developed soil on a pelletal clay sediment indicates the lake is dry, unless there is a lateral equivalent sand dune unit. The first unit is a poorly sorted gravelly sand layer which heralds the first arrival of water in lake. This unit is rarely thick, probably because early in the wetting cycle, groundwater levels are low, and salts may not have yet accumulated in the system. There is probably limited sediment availability and insufficient time for clay to accumulate on the floor or sand along the shore. Later low lake level phases in the cycle are associated with high water tables and high salinities in the groundwater window (Bowler, 1971). 
The next unit, dune sand, indicates a lake full phase, since sand is not produced without wash action at the shore. The environment of deposition is a fore dune on the lake edge and grades down slope into a massive or gravelly sand representing beach sediment. Fore dune sand units are typically steeply bedded (dip angle of repose) and up to $30 \mathrm{~m}$ wavelength dunes. They can contain fine, broken shell fragments (Velesunio), and rare fish otoliths. The sand is usually well sorted, washed and winnowed from older units (such as the benched shore on the Golgol unit). The sediment sometimes coarsens laterally towards the beach from massive fine sand to coarse sand and at the shoreline into pebbles and gravel. Beach units (not shown) are steeply dipping sand interbedded with gravel, often lagged on an older surface. The gravel is sometimes silcrete but usually rounded caliche. The unit may contain weakly developed soils as sand supply along the beach varies. Sand is transported along the shoreface by longshore currents and also deposited as spits. The lack of a delta between Lake Leaghur and Lake Mungo indicates that sediment transport via overflow was suspension load.

Long periods of lake highs result in clay deposition on the lake floor. Upon drying of the lake, the abundant clay is then deflated as clay pellets, accumulated mostly in the back dune setting in the lee of the shoreface dunes. These are typically thin units that conform to preexisting topography. These units are often interbedded with sandy clay or clayey sand. The dunes have a shorter wavelength (3-4 $\mathrm{m})$ than the sandy dunes.

The formation of clay pellets requires lake drying and so where the units are rhythmic, they indicate intermittent lake filling. Pelletal clays often form largely flat lying to shallow dipping dunes. Minor pedogenic zones and clay interbedded subunits indicating some periods of variable lake filling may be interspersed. Sandy lenses often contain shell or otolith fragments indicating lake phases deep and long enough for mussels and fish to survive. The conclusion of the lake filling and drying phase is marked by the development of another soil 
once sediment transport ceases. An indication of age is the degree of decalcification of the soil and the development of caliche (Fig. 10).

\section{DISCUSSION}

\section{Lake level history}

Previous lake level curves for the Willandra Lakes have focused on relative changes and relied on estimating lake levels based on the sedimentology of deflated sediments in associated with lake shorelines (e.g. Bowler et al. (2012)). We follow the same approach here and use the facies model in conjunction with the sediment logs and surveyed shorelines to attempt a finer resolution, absolute lake level curve. We used the results from the Bayesian analyses to determine the duration of lake filling events and intervening lake dry periods (Table 3). We supplemented this dating with the published radiocarbon ages from fossil shells and fish otoliths described above. The lake level history of Lake Mungo (Fig. 11a) is likely to be slightly shorter than lakes further up the Willandra chain, but longer than lakes further down the chain (Bowler et al., 2012). Because the lake level records are likely to be diachronous and the geometry and interlinking of the lake basins varies, the lake level history here is specific to Lake Mungo.

Deposition of lunette sediments from the time of the Upper Mungo Unit to the Zanci Unit was continuous except for brief intervals when the lake was dry and not deflating. It is impossible to subdivide the lunette units lithologically (as shown by the facies model) and this demonstrates that the style of lake filling and emptying was similar throughout most of this period. The lake levels attained during the period are necessarily approximate, since none of our ages were specifically on shoreline sediments. The lake has occupied the same shorelines multiple times through its history. 
We updated the database of Bowler et al. (2012) for Velesunio shell, and Macquaria otolith ages from the sediments and direct ages on the sediments using TL and OSL (Fig. 11b, c). Shell and otolith dates are reliable indicators of multi-year water presence, whereas charcoal does not indicate environmental conditions apart from the presence of woody vegetation (Gillespie, 1998). Interpretation of relative probability plots are subject to several problems, especially oversampling of surficial units and uneven sampling of units of interest. More precise dating produces relatively higher peaks. For Fig. 11c, areas have been normalised to a maximum height of 1 and then added together. The presence of fish and shell fossils through all units demonstrates at least brief periods of deep water and low solute content throughout the sequence. The luminescence dating indicates the bulk of the sampled lunette is of Zanci and Arumpo age and that the errors overlap between the younger units.

Determining lake level history using deflated sediments in the lunette dune is problematic, since shorelines are usually not present in the sequence. Therefore, estimates of lake level have been made based on the sediment types and their association with shoreline altitudes. The stratigraphic sections reveal 6 major drying phases during the Arumpo and 2 within the Zanci. The highest lake level during the Arumpo ( $\sim 27 \mathrm{ka})$ was associated with microbialites in the shallows of the shore edge (Fig. 1). Between inferred lake level highs, levels were fluctuating, possibly on an interannual basis. Therefore, absolute heights and durations are indicative only. For the older part of the curve $(>37.1 \mathrm{ka})$, we used the reconstruction of Bowler et al. (2012) except that we used the measured maximum gravel height at the Joulni exposure $(71 \mathrm{~m})$ to approximately scale lake level depth during this period.

\section{Regional climate change}

Transport of water from the highlands in the east to the western plains of southeastern Australia is recorded in fluvial sedimentation. Late Pleistocene rivers in the Murray-Darling 
Basin were substantially larger and carried coarser bedload (Hesse et al., 2018; Kemp and Spooner, 2007). OSL ages from along the Lachlan River indicate that large sinuous channels were fully established from before $67 \mathrm{ka}$ until before $34 \mathrm{ka}$ (Kemp and Rhodes, 2010; Kemp and Spooner, 2007), covering most of the Lower Mungo phase. From 34 ka to 20 ka bankfull discharges declined (Kemp and Rhodes, 2010). This time period covers most of the Upper Mungo, Arumpo and Zanci phases. Hesse et al. (2018) reviewed discharge estimates for Murray-Darling Basin rivers. In the Lachlan River basin, discharge was highest at $66.6 \mathrm{ka}$ $\left(2512 \mathrm{~m}^{3} \mathrm{~s}^{-1}\right)$ with about 20 times modern discharge. Discharge declined to $915 \mathrm{~m}^{3} \mathrm{~s}^{-1}$ at $24.2 \mathrm{ka}$ then to $772 \mathrm{~m}^{3} \mathrm{~s}^{-1}$ by $18.3 \mathrm{ka}$ and to $219 \mathrm{~m}^{3} \mathrm{~s}^{-1}$ by $16.1 \mathrm{ka}$. Kemp et al. (2017) have established that at $18.4 \mathrm{ka}$, or shortly before, the Willandra Creek at least partly avulsed to a more southerly channel. It remains unclear whether this was due to silting up of the Willandra Creek channel or due to the dramatic drop-off in discharge to near modern levels. However, avulsion explains low lake levels in the Willandra Lakes when cold conditions and glaciers persisted in the Snowy Mountains (Barrows et al., 2001). Overall, higher discharge in the Pleistocene explains why Lake Mungo filled in an otherwise low precipitation environment.

Lake level filling events at Lake Mungo are restricted to the coldest phases of the last glacial cycle (Fig. 11d). No continuous temperature curve is available for mainland Australia, but offshore sea-surface temperatures are similar to Antarctic air temperature reconstructions (Barrows et al., 2007) and probably reflect the pattern of change in southern Australia. Initial lake filling at around $60 \mathrm{ka}$ is similar to the time glaciers appeared in the Snowy Mountains during the last glacial cycle (Barrows et al., 2001; Barrows et al., 2002). The most significant production of sediment onto the lunette occurred during the period when glaciers were present, from the Headley Tarn glaciation through to the Blue Lake glaciation ( 32-19 ka). Maximum cooling occurred when periglacial landforms were most active at $21.9 \pm 0.5 \mathrm{ka}$ (Barrows et al., 2004) and this would have been the time of lowest treeline and highest proportion of 
precipitation stored as snowpack in the mountains. After $19 \mathrm{ka}$, the lake underwent final drying, and the area remained arid through the rest of the late Pleistocene and the Holocene, correlating with rapid SST increase (Fig. 11d). Galloway (1965) established that the late Pleistocene water balance in the eastern highlands was mostly controlled by temperature. Hesse et al. (2018) have re-examined this finding using palaeochannel characteristics in the Murray-Darling Basin. They found that discharge through time was sensitive to temperature change and higher runoff efficiency, which to some extent is also a function of temperature through vegetation cover, snowpack storage and periglacial limit. However, they could not quantify the effect of precipitation and this remains a largely unknown variable. It therefore appears likely that temperature had the greatest impact on the hydrological cycle of the Lachlan River and Willandra Creek.

It was wetter than present at Lake Mungo from $\sim 60 \mathrm{ka}$ until about $19 \mathrm{ka}$. The Willandra Lakes have a surface area of $\sim 1088 \mathrm{~km}^{2}$, and under the present evaporation-precipitation regime would require the total discharge of the modern Lachlan River to fill (Bowler, 1971). Many of the clayey sand pelletal clay sediments in the Arumpo and Zanci units are laminar and this reveals that there was a cyclical nature to the lake emptying and refilling on a very short time scale, either seasonal or on a longer interannual scale, such as in the El Niño-Southern Oscillation. Flow was likely to be very seasonal because of water storage as snow in the upper headwaters of the catchment. Reinfelds et al. (2014) showed the potential sensitivity of runoff in the Snowy Mountains to changes in temperature. Each $1{ }^{\circ} \mathrm{C}$ decrease corresponds to a $17 \%$ increase in the runoff coefficient, possibly increasing runoff by a factor of four. Otoliths indicate longer wet periods where the drying process took place over many years after a lake filling (Long et al., 2014). 


\section{CONCLUSIONS}

1) We used 83 OSL ages to define a new lake level history for Lake Mungo. The presence of water, although intermittently, throughout much of the period from $60-19$ ka provides a context from which to interpret human occupation of the area.

2) The inception of Lake Mungo was in the mid-Pleistocene probably between $256-369 \mathrm{ka}$. A scatter of ages older than 100 ka may indicate discontinuous deposition over several glacial cycles.

3) Lake level fluctuated over a range of about $10 \mathrm{~m}$ and at the lake's deepest level, it would have overflowed sills south to the Joulni depression and north back into the Willandra Creek. The area of lake varied from $164 \mathrm{~km}^{2}$ to only $59 \mathrm{~km}^{2}$.

4) Most of the sediment on the lunette was deposited from $37.1-19.8 \mathrm{ka}$ during a period of drying in southeastern Australia. There were brief hiatuses during this period, but the production of sediment was almost continuous. Adjacent linear dunes were also developed in this interval.

5) The timing of lake filling supports previous observations of increased discharge and sediment supply from the eastern highlands during the coldest periods of the last glacial cycle. This was most likely a result of the combination of higher runoff coefficients combined with lower vegetation cover, increased spring melt and periglacial activity.

6) Widespread erosion of the lunette accompanied the arrival of British pastoralists in the $19^{\text {th }}$ century. Although some erosive surfaces have stabilised, erosion continues through to the present day. 


\section{ACKNOWLEDGEMENTS}

We are grateful to the Three Traditional Tribal Groups, the Paakantji, the Muthi Muthi, and the Ngiyampaa, for permission to work at Lake Mungo. The late Ray Lawson, a Paakantji Elder, provided valuable guidance in the field. Tegan Kelly kindly calculated dose rates from the gamma spectrometric data for KF. Rudy Frank conducted the surveying and participated in many useful discussions in the field. We thank Eva Reynolds and Wayne Cook for help in the Research School of Earth Sciences, Australian National University OSL laboratory. We also thank Jim Bowler for useful discussions in the field. This research was funded as part of Australian Research Council Linkage grant LP0775058, in partnership with the Elders Council of the Three Traditional Tribal Groups and the Lower Darling Branch of the New South Wales Office of Environment and Heritage. Insightful comments from Prof. Martin Williams and reviews from two anonymous reviewers improved the manuscript. 


\section{REFERENCES}

Adamiec, G., Aitken, M.J., 1998. Dose-rate conversion factors: update. Ancient TL 16(2), 37-50.

Adams, G., Mortlock, A.J., 1974. Thermoluminescent Dating of Baked Sand from Fire Hearths at Lake Mungo, New South Wales. Archaeology \& Physical Anthropology in Oceania, 9(3), 236-237.

Barbetti, M., Allen, H., 1972. Prehistoric Man at Lake Mungo, Australia, by 32,000 years BP. Nature, 240(5375), 46-48.

Barbetti, M., Polach, H., 1973. ANU Radiocarbon Date List V. Radiocarbon, 15(2), 241-251.

Barrows, T.T., Juggins, S., De Deckker, P., Calvo, E., Pelejero, C., 2007. Long-term sea-surface temperature and climate change in the Australian-New Zealand region. Paleoceanography, 22, PA 2215 doi:2210.1029/2006PA001328.

Barrows, T.T., Stone, J.O., Fifield, L.K., 2004. Exposure ages for Pleistocene periglacial deposits in Australia. Quaternary Science Reviews, 23(5-6), 697-708.

Barrows, T.T., Stone, J.O., Fifield, L.K., Cresswell, R.G., 2001. Late Pleistocene Glaciation of the Kosciuszko Massif, Snowy Mountains, Australia. Quaternary Research, 55(2), 179-189.

Barrows, T.T., Stone, J.O., Fifield, L.K., Cresswell, R.G., 2002. The timing of the Last Glacial Maximum in Australia. Quaternary Science Reviews, 21(1-3), 159-173.

Barrows, T.T., Williams, M.A.J., Mills, S.C., Duller, G.A.T., Fifield, L.K., Haberlah, D., Tims, S.G., Williams, F.M., 2014. A White Nile megalake during the last interglacial period. Geology, 42(2), 163-166.

Bell, W.T., 1991. Thermoluminescence dates for the Lake Mungo aboriginal fireplaces and the implications for radiocarbon dating. Archaeometry, 33(1), 43-50.

Bøtter-Jensen, L., 1997. Luminescence techniques: instrumentation and methods. Radiation Measurements, 27(5-6), 749-768.

Bøtter-Jensen, L., Bulur, E., Duller, G.A.T., Murray, A.S., 2000. Advances in luminescence instrument systems. Radiation Measurements, 32(5-6), 523-528.

Bowler, J.M., 1971. Pleistocene salinities and climatic change: evidence from Lakes and Lunettes in southeastern Australia. In: D.J. Mulvaney, J. Golson (Eds.), Aboriginal man and environment. ANU Press, Canberra pp. 47-65.

Bowler, J.M., 1976. Aridity in Australia: Age, origins and expression in aeolian landforms and sediments. Earth-Science Reviews, 12(2-3), 279-310.

Bowler, J.M., 1998. Willandra Lakes revisited: environmental framework for human occupation Archaeology in Oceania, $33: 120-155(3)$.

Bowler, J.M., Gillespie, R., Johnston, H., Boljkovac, K., 2012. Wind v Water: Glacial maximum records from the Willandra Lakes. In: S. Haberle, B. David (Eds.), Peopled Landscapes:

Archaeological and Biogeographical Approaches to Landscape. Terra Australis ANU E Press, Canberra, pp. 271-296.

Bowler, J.M., Johnston, H., Olley, J.M., Prescott, J.R., Roberts, R.G., Shawcross, W., Spooner, N.A., 2003. New ages for human occupation and climatic change at Lake Mungo, Australia. Nature, 421(6925), 837-840.

Bowler, J.M., Jones, R., Allen, H., Thorne, A.G., 1970. Pleistocene human remains from Australia: A living site and human cremation from Lake Mungo, western New South Wales. World Archaeology, 2(1), 39-60.

Bowler, J.M., Kotsonis, A., Lawrence, C.R., 2006. Environmental evolution of the Mallee region, Western Murray Basin. Proceedings of the Royal Society of Victoria 118 (2), 161-210.

Bowler, J.M., Magee, J.W., 2000. Redating Australia's oldest human remains: a sceptic's view. Journal of Human Evolution, 38(5), 719-726.

Bowler, J.M., Price, D.M., 1998. Luminescence dates and stratigraphic analyses at Lake Mungo: review and new perspectives Archaeology in Oceania, 33(3), 156-168.

Bowler, J.M., Thorne, A.G., Polach, H.A., 1972. Pleistocene Man in Australia: Age and Significance of the Mungo Skeleton. Nature, 240(5375), 48-50.

Bronk Ramsey, C., 2009. Bayesian Analysis of Radiocarbon Dates. Radiocarbon, 51(1), 337-360.

Bureau of Meteorology, 2020. Climate Data Online.

Burrough, S.L., Thomas, D.S.G., Shaw, P.A., Bailey, R.M., 2007. Multiphase Quaternary highstands at Lake Ngami, Kalahari, northern Botswana. Palaeogeography, Palaeoclimatology, Palaeoecology, 253(3), 280-299.

Clarkson, C., Jacobs, Z., Marwick, B., Fullagar, R., Wallis, L., Smith, M., Roberts, R.G., Hayes, E., Lowe, K., Carah, X., Florin, S.A., McNeil, J., Cox, D., Arnold, L.J., Hua, Q., Huntley, J., Brand, 
H.E.A., Manne, T., Fairbairn, A., Shulmeister, J., Lyle, L., Salinas, M., Page, M., Connell, K., Park, G., Norman, K., Murphy, T., Pardoe, C., 2017. Human occupation of northern Australia by 65,000 years ago. Nature, $547,306$.

Fitzsimmons, K.E., Cohen, T.J., Hesse, P.P., Jansen, J., Nanson, G.C., May, J.-H., Barrows, T.T., Haberlah, D., Hilgers, A., Kelly, T., Larsen, J., Lomax, J., Treble, P., 2013. Late Quaternary palaeoenvironmental change in the Australian drylands. Quaternary Science Reviews, 74, 7896.

Fitzsimmons, K.E., Rhodes, E.J., Barrows, T.T., 2010. OSL dating of southeast Australian quartz: A preliminary assessment of luminescence characteristics and behaviour. Quaternary Geochronology, 5(2-3), 91-95.

Fitzsimmons, K.E., Rhodes, E.J., Magee, J.W., Barrows, T.T., 2007. The timing of linear dune activity in the Strzelecki and Tirari Deserts, Australia. Quaternary Science Reviews, 26(19-21), 25982616.

Fitzsimmons, K.E., Stern, N., Murray-Wallace, C.V., 2014. Depositional history and archaeology of the central Lake Mungo lunette, Willandra Lakes, southeast Australia. Journal of Archaeological Science, 41, 349-364.

Fitzsimmons, K.E., Stern, N., Murray-Wallace, C.V., Truscott, W., Pop, C., 2015. The Mungo MegaLake Event, Semi-Arid Australia: Non-Linear Descent into the Last Ice Age, Implications for Human Behaviour. PLOS ONE, 10(6), e0127008.

Galbraith, R.F., Roberts, R.G., Laslett, G.M., Yoshida, H., Olley, J.M., 1999. Optical dating of single and multiple grains of quartz from Jinmium rock shelter, northern Australia. Part 1, Experimental design and statistical models. Archaeometry, 41(2), 339-364.

Galloway, R.W., 1965. Late Quaternary Climates in Australia. The Journal of Geology, 73(4), 603618.

Gillespie, R., 1997. Burnt and Unburnt Carbon: Dating Charcoal and Burnt Bone from the Willandra Lakes, Australia. Radiocarbon, 39(3), 239-250.

Gillespie, R., 1998. Alternative timescales: a critical review of Willandra Lakes dating Archaeology in Oceania, 33(3), 169-182.

Gillespie, R., Fink, D., Petchey, F., Jacobsen, G., 2009. Murray-Darling basin freshwater shells: riverine reservoir effect. Archaeology in Oceania, 44(2), 107-111.

Hamm, G., Mitchell, P., Arnold, L.J., Prideaux, G.J., Questiaux, D., Spooner, N.A., Levchenko, V.A., Foley, E.C., Worthy, T.H., Stephenson, B., Coulthard, V., Coulthard, C., Wilton, S., Johnston, D., 2016. Cultural innovation and megafauna interaction in the early settlement of arid Australia. Nature, 539, 280.

Hesse, P.P., Williams, R., Ralph, T.J., Fryirs, K.A., Larkin, Z.T., Westaway, K.E., Farebrother, W., 2018. Palaeohydrology of lowland rivers in the Murray-Darling Basin, Australia. Quaternary Science Reviews, 200, 85-105.

Hills, E.S., 1940. The lunette, a new land form of aeolian origin. Australian Geographer, 3(7), $15-21$.

Hogg, A.G., Hua, Q., Blackwell, P.G., Niu, M., Buck, C.E., Guilderson, T.P., Heaton, T.J., Palmer, J.G., Reimer, P.J., Reimer, R.W., Turney, C.S.M., Zimmerman, S.R.H., 2013. SHCal13 Southern Hemisphere Calibration, 0-50,000 Years cal BP. Radiocarbon, 55(4), 1889-1903.

Huxtable, J., Aitken, M.J., 1977. Thermoluminescent dating of Lake Mungo geomagnetic polarity excursion. Nature, 265(5589), 40-41.

Johnston, H., Clark, P., 1998. Willandra Lakes Archaeological Investigations 1968-98. Archaeology in Oceania, 33(3), 105-119.

Kalish, J.M., Miller, G.H., Tuniz, C., Pritchard, J.C., Rosewater, A., Lawson, E., 1997. Otoliths as recorders of palaeoenvironments: comparison of radiocarbon age and isoleucine epimerization in Pleistocene golden perch Macquaria ambigua otoliths from Willandra Lakes, Conference Handbook, Sixth Australasian Archaeometry Conference, Australian Museum, Sydney, 10-13 February 1997.

Kemp, J., Pietsch, T., Gontz, A., Olley, J., 2017. Lacustrine-fluvial interactions in Australia's Riverine Plains. Quaternary Science Reviews, 166, 352-362.

Kemp, J., Rhodes, E.J., 2010. Episodic fluvial activity of inland rivers in southeastern Australia: Palaeochannel systems and terraces of the Lachlan River. Quaternary Science Reviews, 29(5-6), 732-752.

Kemp, J., Spooner, N.A., 2007. Evidence for regionally wet conditions before the LGM in southeast Australia: OSL ages from a large palaeochannel in the Lachlan Valley. Journal of Quaternary Science, 22(5), 423-427.

Last, F.M., Last, W.M., 2015. An Overview of Microbialite Genesis and Composition in Saline Lakes of Southern Australia, Sixth International Limnogeology Congress June 15-19, 2015- 
Abstract Volume. U.S. Geological Survey Open-File Report 2015-1092, Reno, Nevada, pp. 244.

Lomax, J., Hilgers, A., Twidale, C.R., Bourne, J.A., Radtke, U., 2007. Treatment of broad palaeodose distributions in OSL dating of dune sands from the western Murray Basin, South Australia. Quaternary Geochronology, 2(1-4), 51-56.

Long, K., Stern, N., Williams, I.S., Kinsley, L., Wood, R., Sporcic, K., Smith, T., Fallon, S., Kokkonen, H., Moffat, I., Grün, R., 2014. Fish otolith geochemistry, environmental conditions and human occupation at Lake Mungo, Australia. Quaternary Science Reviews, 88, 82-95.

Mejdahl, V., 1979. Thermoluminescence dating: beta-dose attenuation in quartz grains. Archaeometry, 21(1), 61-72.

Miller, G., Magee, J., Smith, M., Spooner, N., Baynes, A., Lehman, S., Fogel, M., Johnston, H., Williams, D., Clark, P., Florian, C., Holst, R., DeVogel, S., 2016. Human predation contributed to the extinction of the Australian megafaunal bird Genyornis newtoni $\sim 47$ ka. Nature Communications, 7, 10496.

Miller, G.H., Magee, J.W., Johnson, B.J., Fogel, M.L., Spooner, N.A., McCulloch, M.T., Ayliffe, L.K., 1999. Pleistocene Extinction of Genyornis newtoni: Human Impact on Australian Megafauna. Science, 283(5399), 205-208.

Miller, G.H., Magee, J.W., Jull, A.J.T., 1997. Low latitude glacial cooling in the Southern Hemisphere from amino acids in emu eggshells. Nature, 385, 241-244.

Murray, A.S., Wintle, A.G., 2000. Luminescence dating of quartz using an improved single-aliquot regenerative-dose protocol. Radiation Measurements, 32(1), 57-73.

Murray, A.S., Wintle, A.G., 2003. The single aliquot regenerative dose protocol: potential for improvements in reliability. Radiation Measurements, 37(4-5), 377-381.

O'Connell, J.F., Allen, J., Williams, M.A.J., Williams, A.N., Turney, C.S.M., Spooner, N.A., Kamminga, J., Brown, G., Cooper, A., 2018. When did $<$ em $>$ Homo sapiens $</$ em $>$ first reach Southeast Asia and Sahul? Proceedings of the National Academy of Sciences, 115(34), 8482-8490.

Olley, J.M., Roberts, R.G., Yoshida, H., Bowler, J.M., 2006. Single-grain optical dating of grave-infill associated with human burials at Lake Mungo, Australia. Quaternary Science Reviews, 25(19-20), 2469-2474.

Oyston, B., 1996. Thermoluminescence age determinations for the Mungo III human burial, Lake Mungo, Southeastern Australia. Quaternary Science Reviews, 15(7), 739-749.

Pietsch, T.J., Olley, J.M., Nanson, G.C., 2008. Fluvial transport as a natural luminescence sensitiser of quartz. Quaternary Geochronology, 3(4), 365-376.

Polach, H.A., Lovering, J.F., Bowler, J.M., 1970. Anu Radiocarbon Date List IV. Radiocarbon, 12(1), 1-18.

Prescott, J.R., Hutton, J.T., 1994. Cosmic ray contributions to dose rates for luminescence and ESR dating: Large depths and long-term time variations. Radiation Measurements, 23(2), 497-500.

Readhead, M.L., 1988. Thermoluminescence dating study of quartz in aeolian sediments from southeastern Australia. Quaternary Science Reviews, 7(3-4), 257-264.

Reeves, J.M., Barrows, T.T., Cohen, T.J., Kiem, A.S., Bostock, H.C., Fitzsimmons, K.E., Jansen, J.D., Kemp, J., Krause, C., Petherick, L., Phipps, S.J., 2013. Climate variability over the last 35,000 years recorded in marine and terrestrial archives in the Australian region: an OZ-INTIMATE compilation. Quaternary Science Reviews, 74, 21-34.

Reimer, P.J., Bard, E., Bayliss, A., Beck, J.W., Blackwell, P.G., Ramsey, C.B., Buck, C.E., Cheng, H., Edwards, R.L., Friedrich, M., Grootes, P.M., Guilderson, T.P., Haflidason, H., Hajdas, I., Hatté, C., Heaton, T.J., Hoffmann, D.L., Hogg, A.G., Hughen, K.A., Kaiser, K.F., Kromer, B., Manning, S.W., Niu, M., Reimer, R.W., Richards, D.A., Scott, E.M., Southon, J.R., Staff, R.A., Turney, C.S.M., van der Plicht, J., 2013. IntCal13 and Marine13 Radiocarbon Age Calibration Curves 0-50,000 Years cal BP. Radiocarbon, 55(4), 1869-1887.

Reinfelds, I., Swanson, E., Cohen, T., Larsen, J., Nolan, A., 2014. Hydrospatial assessment of streamflow yields and effects of climate change: Snowy Mountains, Australia. Journal of Hydrology, 512, 206-220.

Stern, N., 2015. The Archaeology of the Willandra

Its empirical structure and narrative potential. In: A. McGrath, M.A. Jebb (Eds.), Long History, Deep Time. Deepening Histories of Place. ANU Press, pp. 221-240.

Stern, N., Tumney, J., Fitzsimmons, K.E., Kajewski, P., 2013. Strategies for investigating human responses to changes in landscape and climate at lake mungo in the Willandra Lakes, Southeast Australia, Archaeology in Environment and Technology: Intersections and Transformations, pp. 31-50. 
Stirling, E.C., Zeitz, A.H.C., 1900. Fossil remains of Lake Callabonna. 1. Genyornis newtoni. A new genus and species of fossil struthious bird. Memoirs, Royal Society of South Australia, 1, 4180.

Stuiver, M., Reimer, P.J., 1993. Extended ${ }^{14} \mathrm{C}$ data base and revised CALIB $3.0{ }^{14} \mathrm{C}$ age calibration program. Radiocarbon, 35(1), 215-230.

Telfer, M.W., Hesse, P.P., Perez-Fernandez, M., Bailey, R.M., Bajkan, S., Lancaster, N., 2017. Morphodynamics, boundary conditions and pattern evolution within a vegetated linear dunefield. Geomorphology, 290, 85-100.

Thorne, A., Grün, R., Mortimer, G., Spooner, N.A., Simpson, J.J., McCulloch, M., Taylor, L., Curnoe, D., 1999. Australia's oldest human remains: age of the Lake Mungo 3 skeleton. Journal of Human Evolution, 36(6), 591-612.

Tumney, J., 2018. Identifying and characterising different types of stone artefact accumulations on the surface of the Lake Mungo lunette, southwest New South Wales, Australia. Journal of Archaeological Science: Reports, 21, 380-388.

Williams, M., 2014. Climate change in deserts: Past, present and future. Climate Change in Deserts: Past, Present and Future.

Williams, M., Cook, E., van der Kaars, S., Barrows, T., Shulmeister, J., Kershaw, P., 2009. Glacial and deglacial climatic patterns in Australia and surrounding regions from 35[punctuation space]000 to 10[punctuation space]000 years ago reconstructed from terrestrial and nearshore proxy data. Quaternary Science Reviews, 28(23-24), 2398-2419.

Williams, M.A.J., 2019. Termites and stone lines - traps for the unwary archaeologist. Quaternary Science Reviews, 226, 106028.

Yamasaki, F., Hamada, C., Hamada, T., 1977. Riken Natural Radiocarbon Measurements IX. Radiocarbon, 19(1), 62-95. 


\section{TABLES}

Table 1. Lake area and volume for lake levels at Lake Mungo, "+” includes Joulni playas

Table 2. Optically stimulated luminescence data and ages for samples from Lake Mungo.

Table 3. Sedimentary unit boundary ages, duration, interval lengths and their uncertainty at Lake Mungo

\section{FIGURES}

\section{Figure 1}

Map of the Lake Mungo area. Sampling sites BLW1-4 =Blowouts 1 to 4 . MSH = Mungo sandhill 1 sampling site. WOC ="Walls of China" Tourist site. PM= "Palaeomagnetic site". Triangles indicate the lowest point on the lake floor and on the lunette. Also indicated are the position of significant geomorphic features and sites. Inset shows the position of Figure 1 within the Willandra Lakes chain. $\mathrm{LM}=$ Lake Mulurulu, WC=Willandra Creek, LG=Lake Garnpung, $\mathrm{LL}=$ Lake Leaghur, $\mathrm{OA}=$ Outer Arumpo, $\mathrm{CL}=$ Chibnalwood Lakes, $\mathrm{PL}=\mathrm{Prungle}$ Lakes.

\section{Figure 2}

Lake area at Lake Mungo for the area the lake would occupy at the 62, 64, 66, 69 and $71 \mathrm{~m}$ contours. Arrows indicate potential flow directions at sills between Lake Mungo and Joulni (JS), Willandra Creek (WS) and Lake Leaghur (LS).

\section{Figure 3}

Stratigraphic logs and dating results at Blowout 1 (BLW-1). The same legend applies for Figures 5, 7 and 9. Colour scheme is indicative only. 


\section{Figure 4}

$3 \mathrm{D}$ view of Blowout 1 (BLW-1) showing relative position of sampling sites to lunette morphology. S1 is positioned on an inner lunette in front of the main lunette.

\section{Figure 5}

Stratigraphic logs and dating results at Blowout 2 (BLW-2).

\section{Figure 6}

3D view of Blowout 2 (BLW-2) showing relative position of sampling sites to lunette morphology. S1-4 are positioned on an inner lunette in front of the main lunette. Key as for Figure 4.

Figure 7

Stratigraphic logs and dating results at Blowout 3 BLW-3

\section{Figure 8}

3D view of Blowout 3 (BLW-3) showing relative position of sampling sites to lunette morphology. S1-5 are positioned on an inner lunette in front of the main lunette. Key as for Figure 4.

\section{Figure 9}

Stratigraphic logs at Blowout 4 (BLW-4) and Mungo Sandhill 1 (MSH-1).

\section{Figure 10}

Facies model for lunette sediments at Lake Mungo and the basis for interpreting lake levels. Depth is for illustrative purposes only. 


\section{Figure 11}

Panel diagram showing a) Lake level reconstruction, b) Relative probability plot of all luminescence ages from Lake Mungo. White area are previously published ages $(n=101$; see text) and black area are new ages c) Relative probability plot of all otolith ( $\mathrm{n}=41$; white area) and unionid radiocarbon ages ( $\mathrm{n}=10$; black area), d) Sea-surface temperature reconstruction for the Southern Ocean (Barrows et al. 2007). 


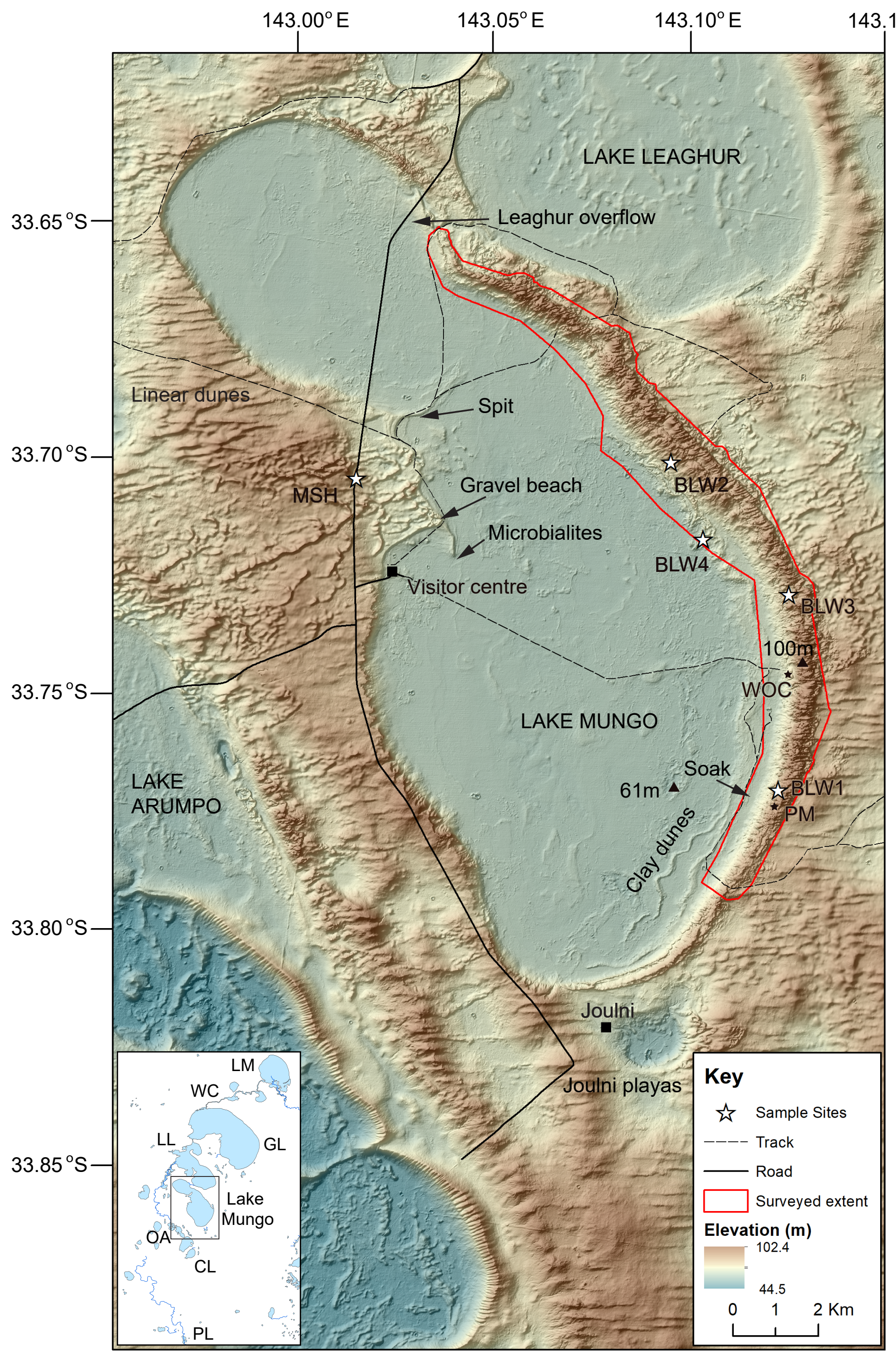




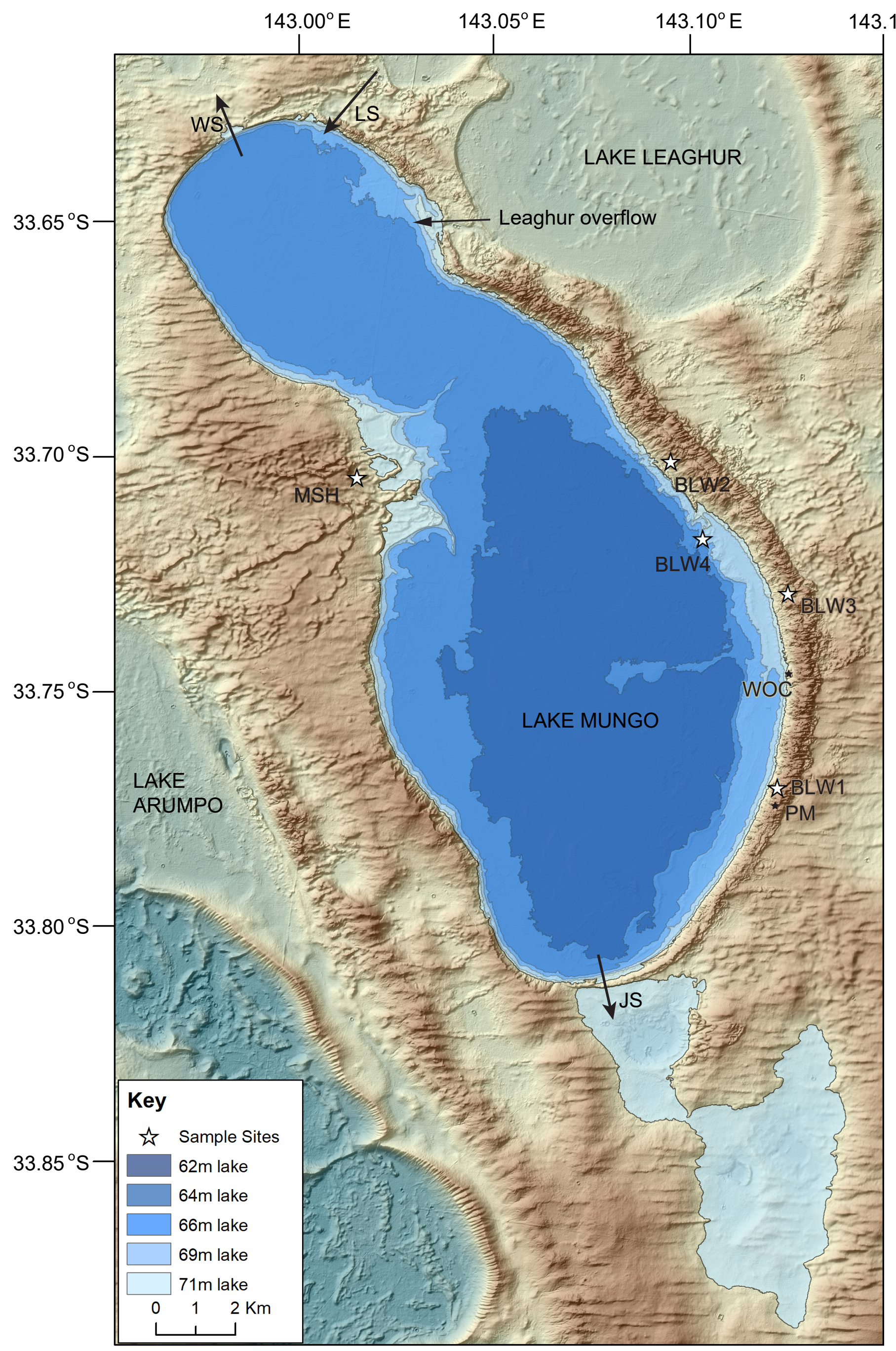




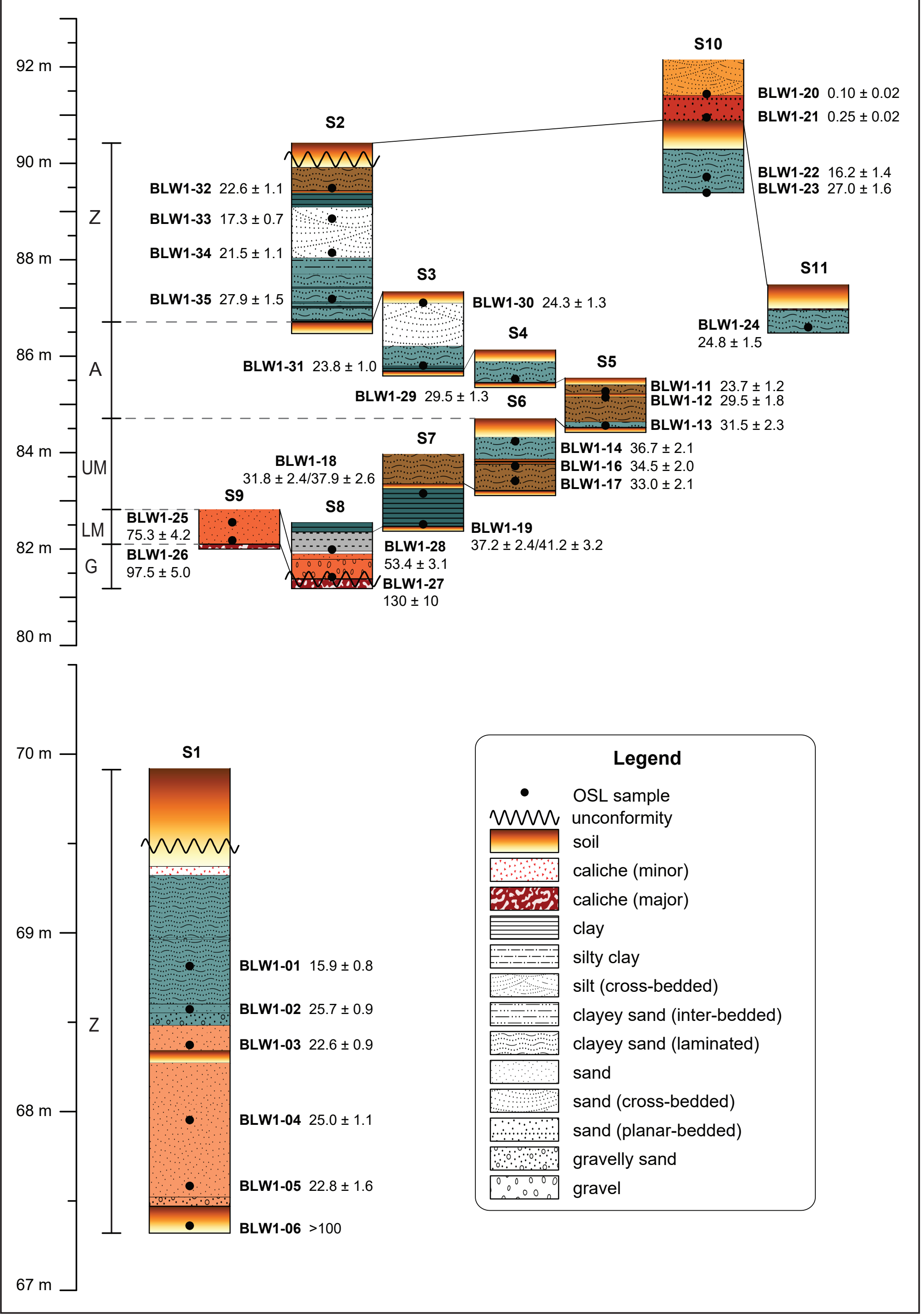




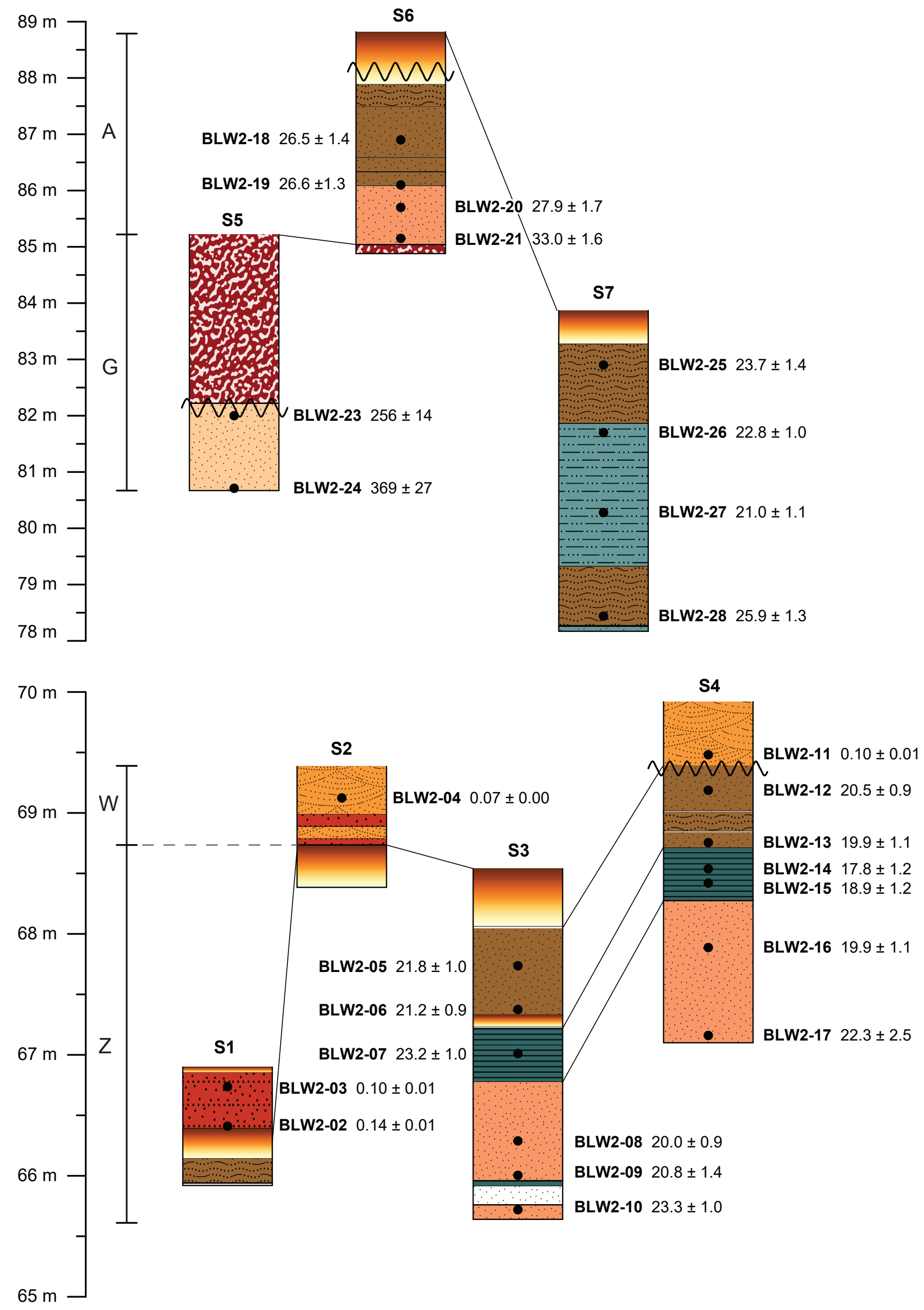




\section{}

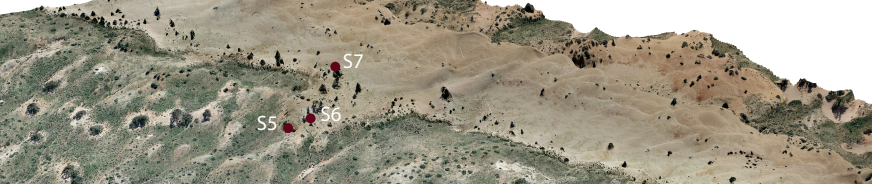

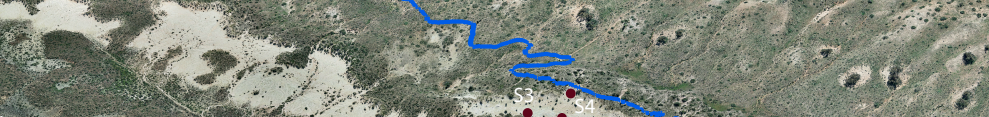

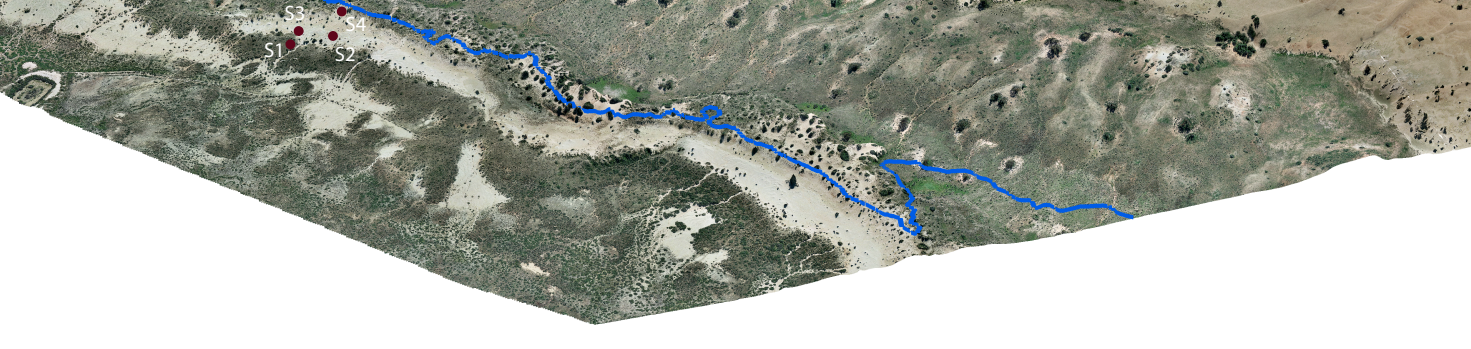




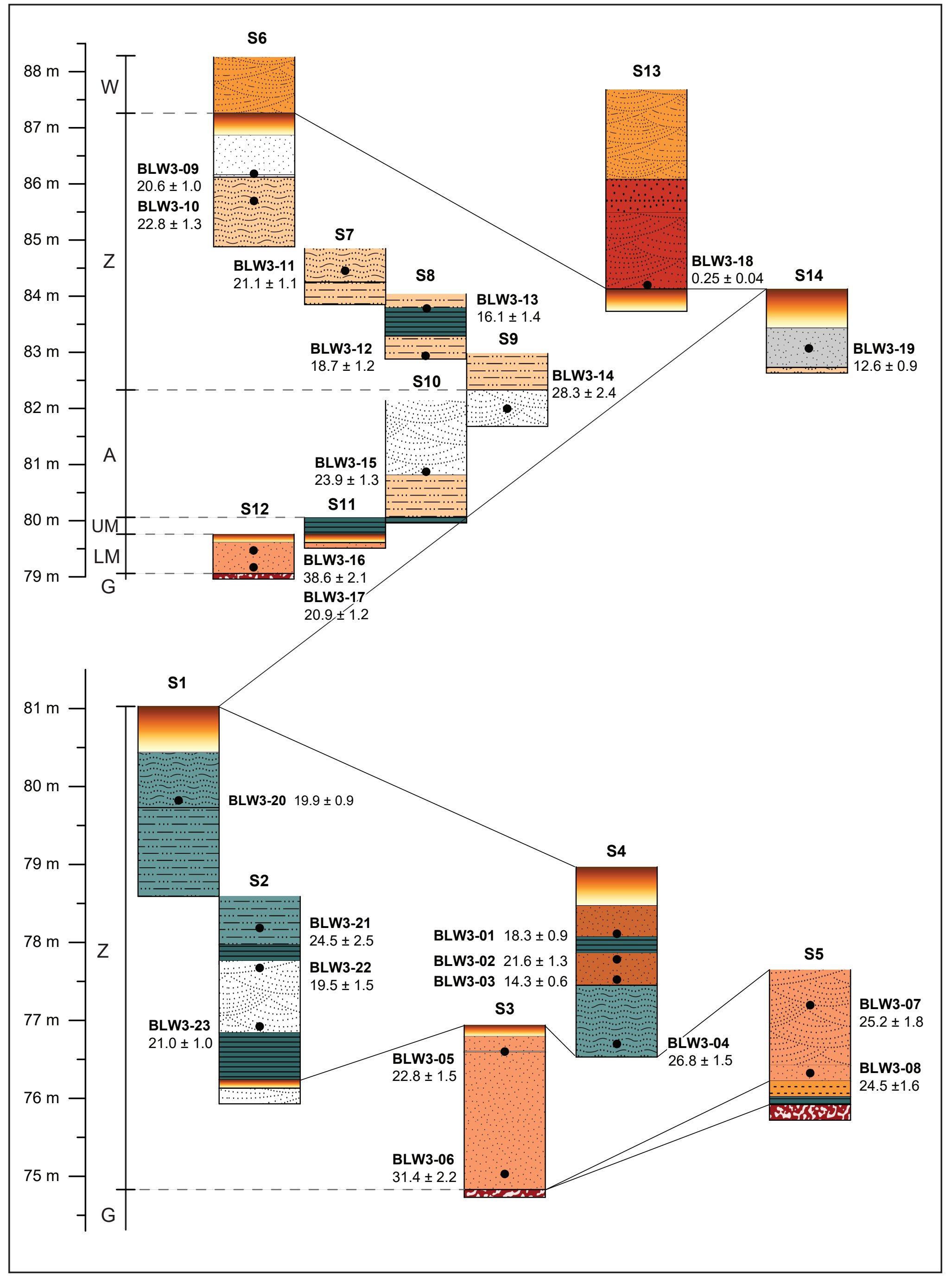




\section{7}

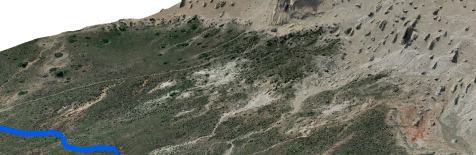
$42-2=-3.5$

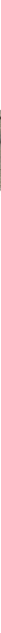




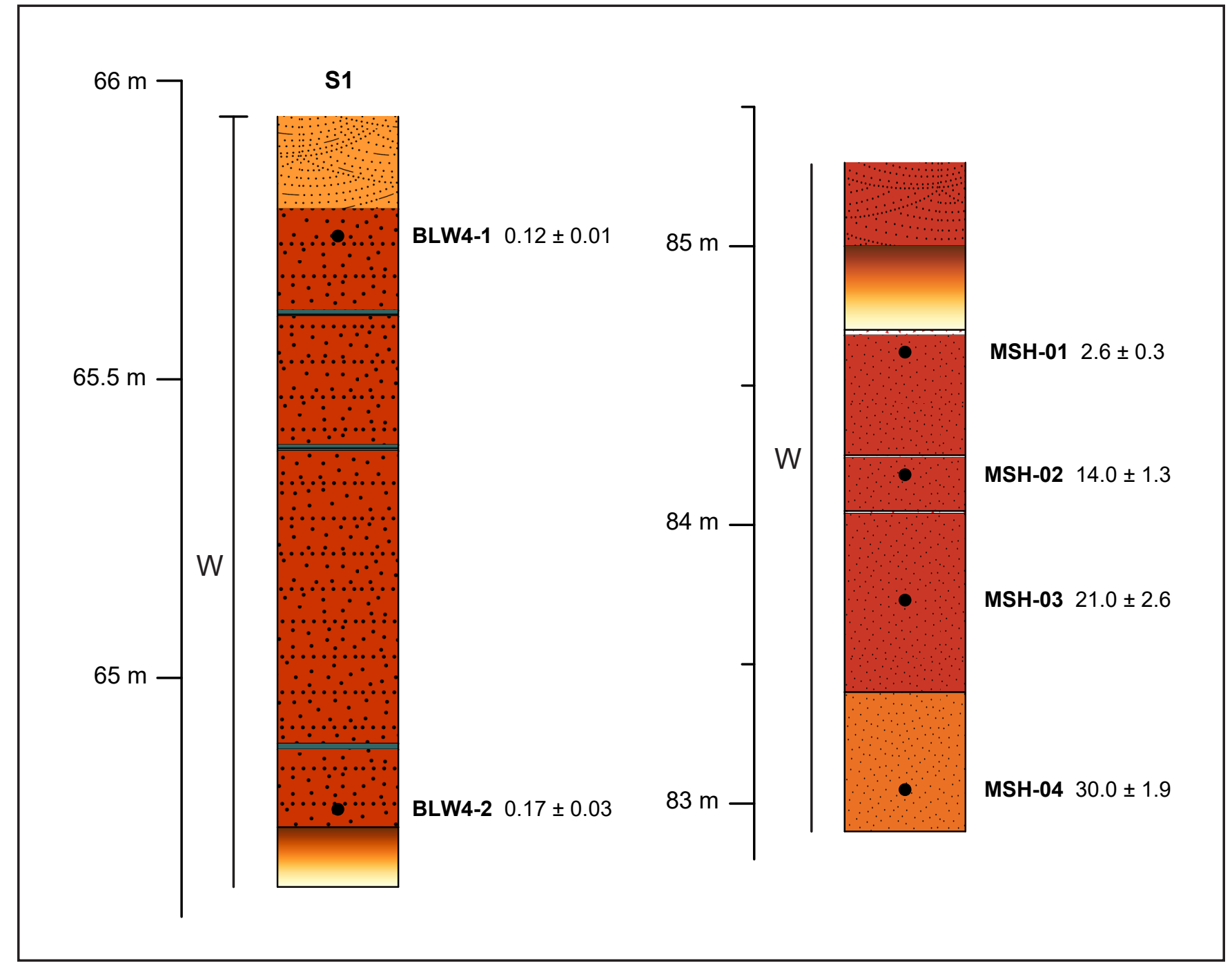




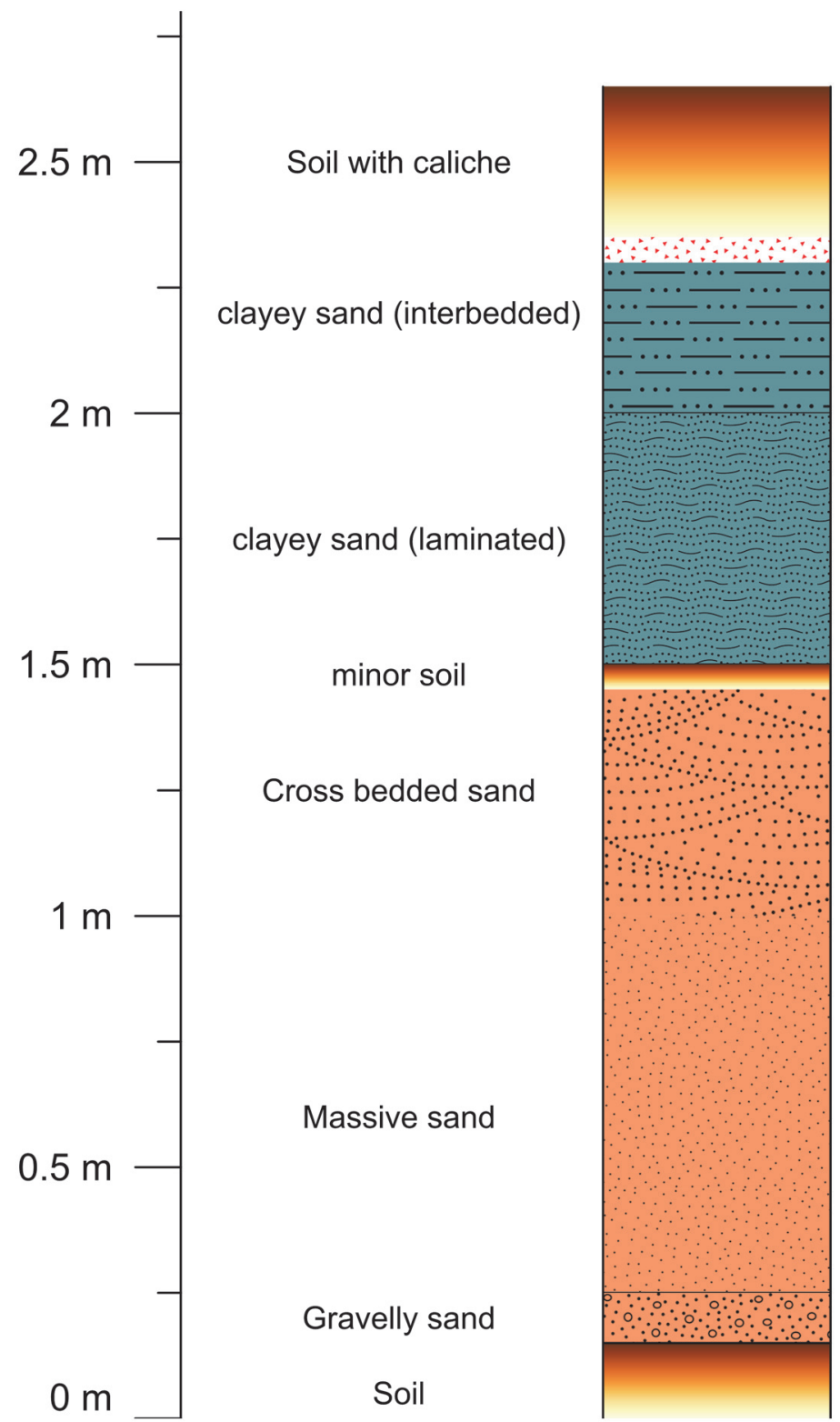

long dry lake interval

lake drying phase (fluctuating)

intermittent lake filling

depositional break

high lake level

early lake filling phase

dry lake 

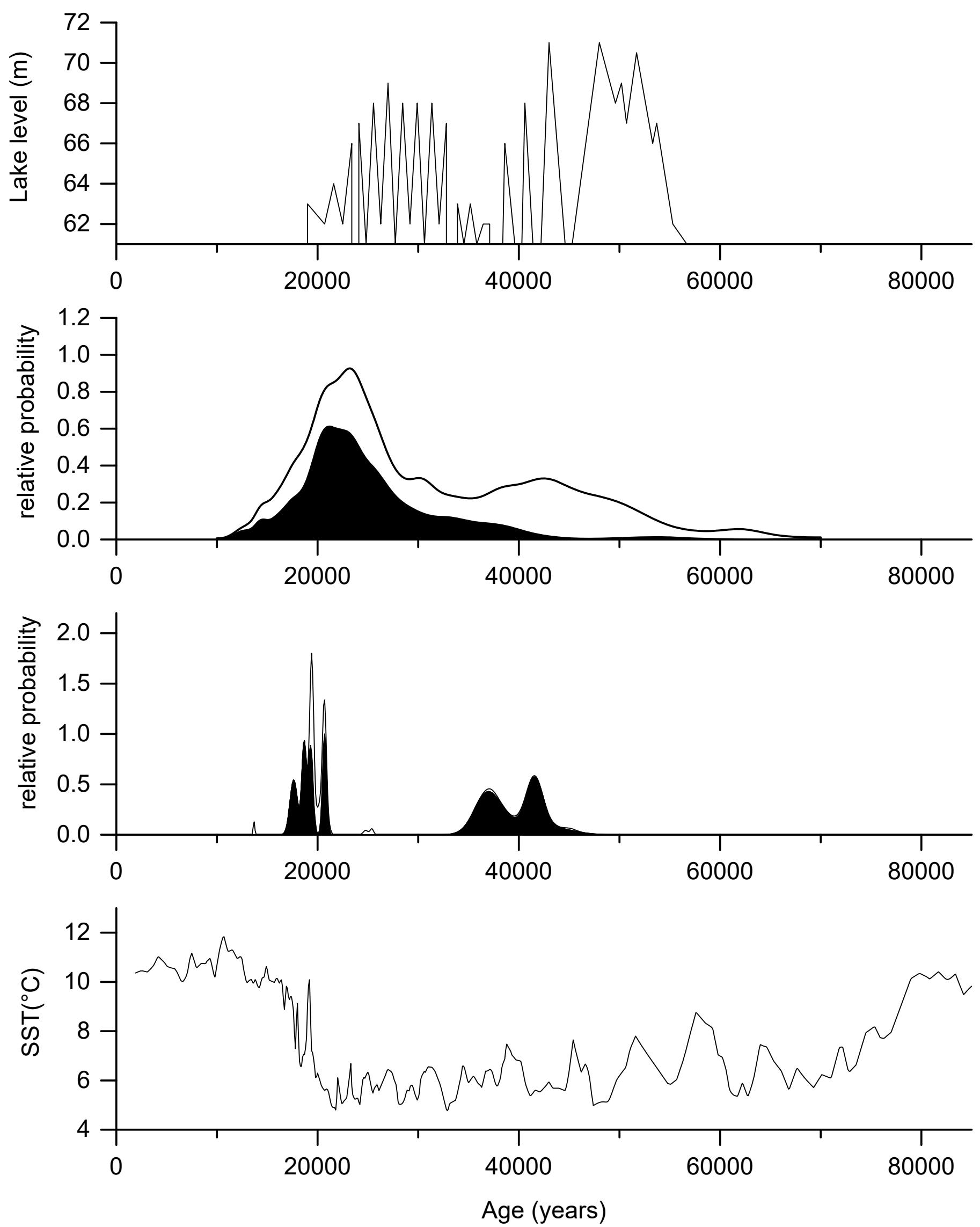
Table 1. Lake area and volume for lake levels at Lake Mungo, “+” includes Joulni playas Lake level Volume $\left(\mathrm{km}_{3}\right)$ Area $\left(\mathrm{km}_{2}\right)$

$\begin{array}{lll}71 \mathrm{~m} & 1.145 & 142 \\ 71 \mathrm{~m}(+) & 0.083 & 22 \\ 69 \mathrm{~m} & 0.865 & 136 \\ 66 \mathrm{~m} & 0.467 & 129 \\ 64 \mathrm{~m} & 0.221 & 116 \\ 62 \mathrm{~m} & 0.028 & 59\end{array}$

Table 3. Sedimentary unit boundary ages, duration, interval lengths and their uncertainty at Lake Mungo.

\begin{tabular}{lllll} 
Member & & Age $(\mathbf{y r})$ & $\pm(\mathbf{y r})$ & $\mathbf{X} 2 / \mathbf{v}$ \\
Zanci & duration & 3500 & 3900 & 553 \\
& upper & 19800 & 1700 & 11.2 \\
& lower & 23400 & 2800 & 4.4 \\
Arumpo & interval & 800 & 300 & 0.1 \\
& duration & 8900 & 600 & 1.1 \\
& upper & 24100 & 1100 & 0.1 \\
& lower & 32800 & 500 & \\
\multirow{2}{*}{ Upper Mungo } & interval & 1200 & 1200 & \\
& duration & 2500 & 2500 &
\end{tabular}


Table 2. Optically stimulated luminescence data and ages for samples from Lake Mungo.

\begin{tabular}{|c|c|c|c|c|c|c|c|c|c|}
\hline Lab ID & $\begin{array}{c}\text { Sample } \\
\text { ID }\end{array}$ & $\begin{array}{c}\text { Depth } \\
\text { (m) }\end{array}$ & $\begin{array}{c}\text { Water } \\
\text { content } \\
(\%)\end{array}$ & DE (Gy) & $\begin{array}{c}\text { Radionuclide } \\
\text { concentrations } \\
\text { K (\%) Th }(\mathrm{ppm}) \mathrm{U}(\mathrm{ppm})\end{array}$ & $\begin{array}{l}\text { External } \\
\text { Y dose } \\
\text { rate } \\
(\text { Gy/ka) }\end{array}$ & $\begin{array}{l}\text { Cosmic } \\
\text { ray dose } \\
\text { rate } \\
(\mathbf{G y} / \mathbf{k a})\end{array}$ & $\begin{array}{l}\text { Total } \\
\text { dose } \\
\text { rate } \\
\text { (Gy/ka) }\end{array}$ & $\begin{array}{l}\text { Age } \\
\text { estimate } \\
\text { (ka) }\end{array}$ \\
\hline
\end{tabular}

\begin{tabular}{|c|c|c|c|c|c|c|c|c|c|c|c|}
\hline \multicolumn{12}{|c|}{ Blowout 1} \\
\hline K2137 & BLW1-01 & 1.11 & $5 \pm 3$ & $\begin{array}{l}20.5 \pm \\
0.7\end{array}$ & $\begin{array}{l}0.78 \pm \\
0.04\end{array}$ & $\begin{array}{l}3.22 \pm \\
0.16\end{array}$ & $\begin{array}{l}0.48 \pm \\
0.02\end{array}$ & $\begin{array}{l}0.44 \pm \\
0.00\end{array}$ & $\begin{array}{l}0.18 \pm \\
0.01\end{array}$ & $\begin{array}{l}1.29 \pm \\
0.05\end{array}$ & $15.9 \pm 0.8$ \\
\hline K2138 & BLW1-O2 & 1.33 & $3 \pm 2$ & $17.1 \pm 0.4$ & $\begin{array}{l}0.18 \pm \\
0.01\end{array}$ & $\begin{array}{l}1.15^{ \pm} \\
0.06\end{array}$ & $\begin{array}{l}0.26 \pm \\
0.01\end{array}$ & $\begin{array}{l}0.31 \pm \\
0.00\end{array}$ & $\begin{array}{l}0.18 \pm \\
0.01\end{array}$ & $\begin{array}{l}0.67 \pm \\
0.02\end{array}$ & $\begin{array}{l}25.7 \pm \\
0.9\end{array}$ \\
\hline K2139 & BLW1-O3 & 1.53 & $3 \pm 2$ & $13.7 \pm 0.3$ & $\begin{array}{l}0.24 \pm \\
0.01\end{array}$ & $\begin{array}{l}1.26 \pm \\
0.06\end{array}$ & $\begin{array}{l}0.24 \pm \\
0.01\end{array}$ & $\begin{array}{l}0.21 \pm \\
0.00\end{array}$ & $\begin{array}{l}0.17 \pm \\
0.01\end{array}$ & $\begin{array}{l}0.61 \pm \\
0.02\end{array}$ & $\begin{array}{l}22.6 \pm \\
0.9\end{array}$ \\
\hline K2140 & BLW1-O4 & 1.95 & $5 \pm 3$ & $14.2 \pm 0.4$ & $\begin{array}{l}0.23 \pm \\
0.01\end{array}$ & $\begin{array}{l}1.53 \pm \\
0.08\end{array}$ & $\begin{array}{l}0.26 \pm \\
0.01\end{array}$ & $\begin{array}{l}0.19 \pm \\
0.00\end{array}$ & $\begin{array}{l}0.16 \pm \\
0.01\end{array}$ & $\begin{array}{l}0.57 \pm \\
0.02\end{array}$ & $25.0 \pm 1.1$ \\
\hline K2141 & BLW1-O5 & 2.32 & $5 \pm 3$ & $14.2 \pm 0.9$ & $\begin{array}{l}0.31 \pm \\
0.02\end{array}$ & $\begin{array}{l}1.57 \pm \\
0.08\end{array}$ & $\begin{array}{l}0.28 \pm \\
0.01\end{array}$ & $\begin{array}{l}0.20 \pm \\
0.00\end{array}$ & $\begin{array}{l}0.16 \pm \\
0.01\end{array}$ & $\begin{array}{l}0.62 \pm \\
0.02\end{array}$ & $22.8 \pm 1.6$ \\
\hline K2142 & BLW1-o6 & 2.54 & $15 \pm 5$ & $>102$ & $\begin{array}{l}0.74 \pm \\
0.04\end{array}$ & $\begin{array}{l}3.31 \pm \\
0.17\end{array}$ & $\begin{array}{l}0.55 \pm \\
0.03\end{array}$ & $\begin{array}{l}0.31 \pm \\
0.00\end{array}$ & $\begin{array}{l}0.15 \pm \\
0.01\end{array}$ & $\begin{array}{l}1.02 \pm \\
0.05\end{array}$ & $>100$ \\
\hline K2147 & BLW1-11 & 3.43 & $5 \pm 3$ & $\begin{array}{l}27.8 \pm \\
0.9\end{array}$ & $\begin{array}{l}0.68 \pm \\
0.03\end{array}$ & $\begin{array}{l}6.29 \pm \\
0.31\end{array}$ & $\begin{array}{l}0.73 \pm \\
0.04\end{array}$ & $\begin{array}{l}0.37 \pm \\
0.00\end{array}$ & $\begin{array}{l}0.14 \pm \\
0.01\end{array}$ & $\begin{array}{l}1.17 \pm \\
0.05\end{array}$ & $23.7 \pm 1.2$ \\
\hline K2148 & BLW1-12 & 3.56 & $5 \pm 3$ & $19.6 \pm 1.0$ & $\begin{array}{l}0.28 \pm \\
0.01\end{array}$ & $\begin{array}{l}2.10 \pm \\
0.11\end{array}$ & $\begin{array}{l}0.26 \pm \\
0.01\end{array}$ & $\begin{array}{l}0.26 \pm \\
0.00\end{array}$ & $\begin{array}{l}0.13 \pm \\
0.01\end{array}$ & $\begin{array}{l}0.67 \pm \\
0.02\end{array}$ & $29.5 \pm 1.8$ \\
\hline K2149 & BLW1-13 & 4.14 & $5 \pm 3$ & $29.4 \pm 1.8$ & $\begin{array}{l}0.55 \pm \\
0.03\end{array}$ & $\begin{array}{l}2.79 \pm \\
0.14\end{array}$ & $\begin{array}{l}0.30 \pm \\
0.02\end{array}$ & $\begin{array}{l}0.33 \pm \\
0.00\end{array}$ & $\begin{array}{l}0.12 \pm \\
0.01\end{array}$ & $\begin{array}{l}0.93 \pm \\
0.04\end{array}$ & $31.5 \pm 2.3$ \\
\hline K215O & BLW1-14 & 3.71 & $5 \pm 3$ & $\begin{array}{l}42.2 \pm \\
2.0\end{array}$ & $\begin{array}{l}0.58 \pm \\
0.03\end{array}$ & $\begin{array}{l}3.34 \pm \\
0.17\end{array}$ & $\begin{array}{l}0.39 \pm \\
0.02\end{array}$ & $\begin{array}{l}0.50 \pm \\
0.00\end{array}$ & $\begin{array}{l}0.13 \pm \\
0.01\end{array}$ & $\begin{array}{l}1.15 \pm \\
0.04\end{array}$ & $36.7 \pm 2.1$ \\
\hline K2152 & BLW1-16 & 4.22 & $5 \pm 3$ & $40.5 \pm 1.8$ & $\begin{array}{l}0.65 \pm \\
0.03\end{array}$ & $\begin{array}{l}2.92 \pm \\
0.15\end{array}$ & $\begin{array}{l}0.36 \pm \\
0.02\end{array}$ & $\begin{array}{l}0.49 \pm \\
0.00\end{array}$ & $\begin{array}{l}0.12 \pm \\
0.01\end{array}$ & $\begin{array}{l}1.17 \pm \\
0.04\end{array}$ & $\begin{array}{l}34.5 \pm \\
2.0\end{array}$ \\
\hline
\end{tabular}




\begin{tabular}{|c|c|c|c|c|c|c|c|c|c|c|c|}
\hline K2153 & BLW1-17 & 4.53 & $5 \pm 3$ & $\begin{array}{l}63.3 \pm \\
2.9\end{array}$ & $\begin{array}{l}1.36 \pm \\
0.07\end{array}$ & $\begin{array}{l}5.54 \pm \\
0.28\end{array}$ & $\begin{array}{l}0.70 \pm \\
0.04\end{array}$ & $\begin{array}{l}0.68 \pm \\
0.00\end{array}$ & $\begin{array}{l}0.12 \pm \\
0.01\end{array}$ & $\begin{array}{l}1.92 \pm \\
0.09\end{array}$ & $33.0 \pm 2.1$ \\
\hline K2154 & $\begin{array}{l}\text { BLW1-18 } \\
\mathrm{a}\end{array}$ & 4.56 & $5 \pm 3$ & $\begin{array}{l}80.8 \pm \\
5.0\end{array}$ & $\begin{array}{l}1.83 \pm \\
0.09\end{array}$ & $\begin{array}{l}10.15 \pm \\
0.51\end{array}$ & $\begin{array}{l}0.94 \pm \\
0.05\end{array}$ & $\begin{array}{l}0.90 \pm \\
0.01\end{array}$ & $\begin{array}{l}0.12 \pm \\
0.01\end{array}$ & $\begin{array}{l}2.54 \pm \\
0.11\end{array}$ & $31.8 \pm 2.4$ \\
\hline K2155 & $\begin{array}{l}\text { BLW1-18 } \\
\text { b }\end{array}$ & 4.56 & $5 \pm 3$ & $\begin{array}{l}97.0 \pm \\
5.0\end{array}$ & $\begin{array}{l}1.90 \pm \\
0.09\end{array}$ & $\begin{array}{l}8.85 \pm \\
0.44\end{array}$ & $\begin{array}{l}0.96 \pm \\
0.05\end{array}$ & $\begin{array}{l}0.90 \pm \\
0.01\end{array}$ & $\begin{array}{l}0.12 \pm \\
0.01\end{array}$ & $\begin{array}{l}2.56 \pm \\
0.12\end{array}$ & $37.9 \pm 2.6$ \\
\hline K2156 & $\begin{array}{l}\text { BLW1-19 } \\
\text { a }\end{array}$ & 5.21 & $5 \pm 3$ & $\begin{array}{l}98.6 \pm \\
3.8\end{array}$ & $\begin{array}{l}2.13 \pm \\
0.11\end{array}$ & $\begin{array}{l}9.46 \pm \\
0.47\end{array}$ & $\begin{array}{l}1.11 \pm \\
0.06\end{array}$ & $\begin{array}{l}0.81 \pm \\
0.01\end{array}$ & $\begin{array}{l}0.11 \pm \\
0.01\end{array}$ & $\begin{array}{l}2.65 \pm \\
0.13\end{array}$ & $37.2 \pm 2.4$ \\
\hline K2157 & $\begin{array}{l}\text { BLW1-19 } \\
\text { b }\end{array}$ & 5.21 & $5 \pm 3$ & $107 \pm 6$ & $\begin{array}{l}2.05 \pm \\
0.10\end{array}$ & $\begin{array}{l}9.00 \pm \\
0.45\end{array}$ & $\begin{array}{l}1.21 \pm \\
0.06\end{array}$ & $\begin{array}{l}0.81 \pm \\
0.01\end{array}$ & $\begin{array}{l}0.11 \pm \\
0.01\end{array}$ & $\begin{array}{l}2.60 \pm \\
0.13\end{array}$ & $41.2 \pm 3.2$ \\
\hline K2158 & BLW1-20 & 0.71 & $5 \pm 3$ & $\begin{array}{l}0.07 \pm \\
0.01\end{array}$ & $\begin{array}{l}0.33 \pm \\
0.02\end{array}$ & $\begin{array}{l}1.84 \pm \\
0.09\end{array}$ & $\begin{array}{l}0.24 \pm \\
0.01\end{array}$ & $\begin{array}{l}0.19 \pm \\
0.01\end{array}$ & $\begin{array}{l}0.19 \pm \\
0.02\end{array}$ & $\begin{array}{l}0.68 \pm \\
0.03\end{array}$ & $\begin{array}{l}0.10 \pm \\
0.02\end{array}$ \\
\hline K2159 & BLW1-21 & 1.16 & $3 \pm 2$ & $\begin{array}{l}0.12 \pm \\
0.01\end{array}$ & $\begin{array}{l}0.18 \pm \\
0.01\end{array}$ & $\begin{array}{l}1.12 \pm \\
0.06\end{array}$ & $\begin{array}{l}0.20 \pm \\
0.01\end{array}$ & $\begin{array}{l}0.12 \pm \\
0.01\end{array}$ & $\begin{array}{l}0.18 \pm \\
0.01\end{array}$ & $\begin{array}{l}0.48 \pm \\
0.02\end{array}$ & $\begin{array}{l}0.25 \pm \\
0.02\end{array}$ \\
\hline K2160 & BLW1-22 & 1.37 & $5 \pm 3$ & $8.7 \pm 0.6$ & $\begin{array}{l}0.29 \pm \\
0.01\end{array}$ & $\begin{array}{l}1.68 \pm \\
0.08\end{array}$ & $\begin{array}{l}0.19 \pm \\
0.01\end{array}$ & $\begin{array}{l}0.10 \pm \\
0.01\end{array}$ & $\begin{array}{l}0.18 \pm \\
0.01\end{array}$ & $\begin{array}{l}0.54 \pm \\
0.02\end{array}$ & $16.2 \pm 1.4$ \\
\hline K2161 & BLW1-23 & 1.7 & $3 \pm 2$ & $11.3 \pm 0.5$ & $\begin{array}{l}0.17 \pm \\
0.01\end{array}$ & $\begin{array}{l}1.22 \pm \\
0.06\end{array}$ & $\begin{array}{l}0.20 \pm \\
0.01\end{array}$ & $\begin{array}{l}0.08 \pm \\
0.00\end{array}$ & $\begin{array}{l}0.17 \pm \\
0.01\end{array}$ & $\begin{array}{l}0.42 \pm \\
0.02\end{array}$ & $27.0 \pm 1.6$ \\
\hline K2162 & BLW1-24 & 0.88 & $5 \pm 3$ & $15.0 \pm 0.6$ & $\begin{array}{l}0.34 \pm \\
0.02\end{array}$ & $\begin{array}{l}1.88 \pm \\
0.09\end{array}$ & $\begin{array}{l}0.23 \pm \\
0.01\end{array}$ & $\begin{array}{l}0.12 \pm \\
0.01\end{array}$ & $\begin{array}{l}0.19 \pm \\
0.01\end{array}$ & $\begin{array}{l}0.60 \pm \\
0.03\end{array}$ & $24.8 \pm 1.5$ \\
\hline K2163 & BLW1-25 & 4.71 & $5 \pm 3$ & $57.9 \pm 2.5$ & $\begin{array}{l}0.40 \pm \\
0.02\end{array}$ & $\begin{array}{l}2.64 \pm \\
0.13\end{array}$ & $\begin{array}{l}0.32 \pm \\
0.02\end{array}$ & $\begin{array}{l}0.28 \pm \\
0.00\end{array}$ & $\begin{array}{l}0.17 \pm \\
0.01\end{array}$ & $\begin{array}{l}0.77 \pm \\
0.03\end{array}$ & $75 \cdot 3 \pm 4.2$ \\
\hline K2164 & BLW1-26 & 5.09 & $3 \pm 2$ & $61.7 \pm 2.4$ & $\begin{array}{l}0.28 \pm \\
0.01\end{array}$ & $\begin{array}{l}2.10 \pm \\
0.11\end{array}$ & $\begin{array}{l}0.29 \pm \\
0.01\end{array}$ & $\begin{array}{l}0.25 \pm \\
0.00\end{array}$ & $\begin{array}{l}0.11 \pm \\
0.01\end{array}$ & $\begin{array}{l}0.63 \pm \\
0.02\end{array}$ & $97.5 \pm 5.0$ \\
\hline K2165 & BLW1-27 & 6.05 & $3 \pm 2$ & $144 \pm 9$ & $\begin{array}{l}0.67 \pm \\
0.03\end{array}$ & $\begin{array}{l}3.88 \pm \\
0.19\end{array}$ & $\begin{array}{l}0.53 \pm \\
0.03\end{array}$ & $\begin{array}{l}0.40 \pm \\
0.00\end{array}$ & $\begin{array}{l}0.10 \pm \\
0.01\end{array}$ & $\begin{array}{l}1.10 \pm \\
0.04\end{array}$ & $130 \pm 10$ \\
\hline K2166 & BLW1-28 & 5.48 & $3 \pm 2$ & $70.9 \pm 3.1$ & $\begin{array}{l}0.79 \pm \\
0.04\end{array}$ & $\begin{array}{l}4.76 \pm \\
0.24\end{array}$ & $\begin{array}{l}0.60 \pm \\
0.03\end{array}$ & $\begin{array}{l}0.51 \pm \\
0.00\end{array}$ & $\begin{array}{l}0.11 \pm \\
0.01\end{array}$ & $\begin{array}{l}1.33 \pm \\
0.05\end{array}$ & $53.4 \pm 3.1$ \\
\hline
\end{tabular}




\begin{tabular}{|c|c|c|c|c|c|c|c|c|c|c|c|}
\hline K2167 & BLW1-29 & 4.88 & $3 \pm 2$ & $14.0 \pm 0.5$ & $\begin{array}{l}0.12 \pm \\
0.01\end{array}$ & $\begin{array}{l}1.17 \pm \\
0.06\end{array}$ & $\begin{array}{l}0.22 \pm \\
0.01\end{array}$ & $\begin{array}{l}0.22 \pm \\
0.00\end{array}$ & $\begin{array}{l}0.11 \pm \\
0.01\end{array}$ & $\begin{array}{l}0.47 \pm \\
0.01\end{array}$ & $29.5 \pm 1.3$ \\
\hline K2168 & BLW1-30 & $3 \cdot 3$ & $5 \pm 3$ & $15.1 \pm 0.7$ & $\begin{array}{l}0.21 \pm \\
0.01\end{array}$ & $\begin{array}{l}1.63 \pm \\
0.08\end{array}$ & $\begin{array}{l}0.20 \pm \\
0.01\end{array}$ & $\begin{array}{l}0.28 \pm \\
0.00\end{array}$ & $\begin{array}{l}0.14 \pm \\
0.01\end{array}$ & $\begin{array}{l}0.62 \pm \\
0.02\end{array}$ & $24.3 \pm 1.3$ \\
\hline K2169 & BLW1-31 & 4.6 & $5 \pm 3$ & $14.1 \pm 0.4$ & $\begin{array}{l}0.25 \pm \\
0.01\end{array}$ & $\begin{array}{l}1.95 \pm \\
0.10\end{array}$ & $\begin{array}{l}0.29 \pm \\
0.01\end{array}$ & $\begin{array}{l}0.23 \pm \\
0.00\end{array}$ & $\begin{array}{l}0.12 \pm \\
0.01\end{array}$ & $\begin{array}{l}0.59 \pm \\
0.02\end{array}$ & $23.8 \pm 1.0$ \\
\hline K2170 & BLW1-32 & 0.92 & $3 \pm 2$ & $17.6 \pm 0.6$ & $\begin{array}{l}0.33 \pm \\
0.02\end{array}$ & $\begin{array}{l}1.94 \pm \\
0.10\end{array}$ & $\begin{array}{l}0.29 \pm \\
0.01\end{array}$ & $\begin{array}{l}0.29 \pm \\
0.00\end{array}$ & $\begin{array}{l}0.19 \pm \\
0.01\end{array}$ & $\begin{array}{l}0.78 \pm \\
0.03\end{array}$ & $22.6 \pm 1.1$ \\
\hline K2171 & BLW1-33 & 1.55 & $5 \pm 3$ & $9.2 \pm 0.2$ & $\begin{array}{l}0.18 \pm \\
0.01\end{array}$ & $\begin{array}{l}1.11 \pm \\
0.06\end{array}$ & $\begin{array}{l}0.20 \pm \\
0.01\end{array}$ & $\begin{array}{l}0.19 \pm \\
0.00\end{array}$ & $\begin{array}{l}0.17 \pm \\
0.01\end{array}$ & $\begin{array}{l}0.53 \pm \\
0.02\end{array}$ & $17.3 \pm 0.7$ \\
\hline K2172 & BLW1-34 & 2.26 & $5 \pm 3$ & $15.8 \pm 0.5$ & $\begin{array}{l}0.41 \pm \\
0.02\end{array}$ & $\begin{array}{l}1.93 \pm \\
0.10\end{array}$ & $\begin{array}{l}0.27 \pm \\
0.01\end{array}$ & $\begin{array}{l}0.22 \pm \\
0.00\end{array}$ & $\begin{array}{l}0.16 \pm \\
0.01\end{array}$ & $\begin{array}{l}0.74 \pm \\
0.03\end{array}$ & $21.5 \pm 1.1$ \\
\hline K2173 & BLW1-35 & 3.22 & $5 \pm 3$ & $25.6 \pm 1.0$ & $\begin{array}{l}0.46 \pm \\
0.02\end{array}$ & $\begin{array}{l}2.10 \pm \\
0.11\end{array}$ & $\begin{array}{l}0.27 \pm \\
0.01\end{array}$ & $\begin{array}{l}0.38 \pm \\
0.00\end{array}$ & $\begin{array}{l}0.14 \pm \\
0.01\end{array}$ & $\begin{array}{l}0.92 \pm \\
0.03\end{array}$ & $27.9 \pm 1.5$ \\
\hline \multicolumn{12}{|c|}{ Blowout 2} \\
\hline K2175 & BLW2-O2 & 0.50 & $3 \pm 2$ & $\begin{array}{l}0.13 \pm \\
0.01\end{array}$ & $\begin{array}{l}0.51 \pm \\
0.03\end{array}$ & $\begin{array}{l}2.86 \pm \\
0.14\end{array}$ & $\begin{array}{l}0.33 \pm \\
0.02\end{array}$ & $\begin{array}{l}0.30 \pm \\
0.00\end{array}$ & $\begin{array}{l}0.20 \pm \\
0.02\end{array}$ & $\begin{array}{l}0.96 \pm \\
0.04\end{array}$ & $\begin{array}{l}0.14 \pm \\
0.01\end{array}$ \\
\hline K2176 & BLW2-O3 & 0.15 & $3 \pm 2$ & $\begin{array}{l}0.09 \pm \\
0.01\end{array}$ & $\begin{array}{l}0.44 \pm \\
0.02\end{array}$ & $\begin{array}{l}2.58 \pm \\
0.13\end{array}$ & $\begin{array}{l}0.33 \pm \\
0.02\end{array}$ & $\begin{array}{l}0.32 \pm \\
0.00\end{array}$ & $\begin{array}{l}0.21 \pm \\
0.03\end{array}$ & $\begin{array}{l}0.93 \pm \\
0.04\end{array}$ & $\begin{array}{l}0.10 \pm \\
0.01\end{array}$ \\
\hline K2177 & BLW2-O4 & 0.27 & $5 \pm 3$ & $\begin{array}{l}0.09 \pm \\
0.00\end{array}$ & $\begin{array}{l}0.71 \pm \\
0.04\end{array}$ & $\begin{array}{l}3.33 \pm \\
0.17\end{array}$ & $\begin{array}{l}0.44 \pm \\
0.02\end{array}$ & $\begin{array}{l}0.37 \pm \\
0.00\end{array}$ & $\begin{array}{l}0.20 \pm \\
0.02\end{array}$ & $\begin{array}{l}1.18 \pm \\
0.05\end{array}$ & $\begin{array}{l}0.07 \pm \\
0.00\end{array}$ \\
\hline K2178 & BLW2-O5 & 0.80 & $3 \pm 2$ & $\begin{array}{l}21.9 \pm \\
0.53\end{array}$ & $\begin{array}{l}0.53 \pm \\
0.03\end{array}$ & $\begin{array}{l}2.60 \pm \\
0.13\end{array}$ & $\begin{array}{l}0.35 \pm \\
0.02\end{array}$ & $\begin{array}{l}0.35 \pm \\
0.00\end{array}$ & $\begin{array}{l}0.19 \pm \\
0.01\end{array}$ & $\begin{array}{l}1.01 \pm \\
0.04\end{array}$ & $21.8 \pm 1.0$ \\
\hline K2179 & BLW2-06 & 1.14 & $3 \pm 2$ & $\begin{array}{l}23.4 \pm \\
0.56\end{array}$ & $\begin{array}{l}0.58 \pm \\
0.03\end{array}$ & $\begin{array}{l}3.07 \pm \\
0.15\end{array}$ & $\begin{array}{l}0.40 \pm \\
0.02\end{array}$ & $\begin{array}{l}0.41 \pm \\
0.00\end{array}$ & $\begin{array}{l}0.18 \pm \\
0.01\end{array}$ & $\begin{array}{l}1.10 \pm \\
0.04\end{array}$ & $21.2 \pm 0.9$ \\
\hline K2180 & BLW2-07 & 1.51 & $3 \pm 2$ & $\begin{array}{l}26.5 \pm \\
0.61\end{array}$ & $\begin{array}{l}0.59 \pm \\
0.03\end{array}$ & $\begin{array}{l}2.98 \pm \\
0.15\end{array}$ & $\begin{array}{l}0.41 \pm \\
0.02\end{array}$ & $\begin{array}{l}0.45 \pm \\
0.00\end{array}$ & $\begin{array}{l}0.17 \pm \\
0.01\end{array}$ & $\begin{array}{l}1.14 \pm \\
0.04\end{array}$ & $23.2 \pm 1.0$ \\
\hline K2181 & BLW2-O8 & 2.23 & $3 \pm 2$ & $12.0 \pm$ & $0.22 \pm$ & $1.29 \pm$ & $0.21 \pm$ & $0.23 \pm$ & $0.16 \pm$ & $0.60 \pm$ & $20.0 \pm$ \\
\hline
\end{tabular}




\begin{tabular}{|c|c|c|c|c|c|c|c|c|c|c|c|}
\hline & & & & 0.38 & 0.01 & 0.06 & 0.01 & 0.00 & 0.03 & 0.02 & 0.9 \\
\hline K2182 & BLW2-09 & 2.51 & $10 \pm 5$ & $\begin{array}{l}16.0 \pm \\
0.86\end{array}$ & $\begin{array}{l}0.44 \pm \\
0.02\end{array}$ & $\begin{array}{l}2.57 \pm \\
0.13\end{array}$ & $\begin{array}{l}0.37 \pm \\
0.02\end{array}$ & $\begin{array}{l}0.25 \pm \\
0.00\end{array}$ & $\begin{array}{l}0.15 \pm \\
0.01\end{array}$ & $\begin{array}{l}0.77 \pm \\
0.03\end{array}$ & $20.8 \pm 1.4$ \\
\hline K2183 & BLW2-10 & 2.80 & $5 \pm 3$ & $14.4 \pm 0.3$ & $\begin{array}{l}0.31 \pm \\
0.02\end{array}$ & $\begin{array}{l}2.01 \pm \\
0.10\end{array}$ & $\begin{array}{l}0.26 \pm \\
0.01\end{array}$ & $\begin{array}{l}0.19 \pm \\
0.00\end{array}$ & $\begin{array}{l}0.15 \pm \\
0.01\end{array}$ & $\begin{array}{l}0.62 \pm \\
0.02\end{array}$ & $23.3 \pm 1.0$ \\
\hline K2184 & BLW2-11 & 0.42 & $3 \pm 2$ & $\begin{array}{l}0.12 \pm \\
0.01\end{array}$ & $\begin{array}{l}0.72 \pm \\
0.04\end{array}$ & $\begin{array}{l}3.89 \pm \\
0.19\end{array}$ & $\begin{array}{l}0.46 \pm \\
0.02\end{array}$ & $\begin{array}{l}0.37 \pm \\
0.00\end{array}$ & $\begin{array}{l}0.20 \pm \\
0.02\end{array}$ & $\begin{array}{l}1.20 \pm \\
0.05\end{array}$ & $\begin{array}{l}0.10 \pm \\
0.01\end{array}$ \\
\hline K2185 & BLW2-12 & 0.71 & $3 \pm 2$ & $21.1 \pm 0.5$ & $\begin{array}{l}0.56 \pm \\
0.03\end{array}$ & $\begin{array}{l}2.69 \pm \\
0.13\end{array}$ & $\begin{array}{l}0.34 \pm \\
0.02\end{array}$ & $\begin{array}{l}0.35 \pm \\
0.00\end{array}$ & $\begin{array}{l}0.19 \pm \\
0.02\end{array}$ & $\begin{array}{l}1.03 \pm \\
0.04\end{array}$ & $\begin{array}{l}20.5 \pm \\
0.9\end{array}$ \\
\hline K2186 & BLW2-13 & 1.13 & $3 \pm 2$ & $\begin{array}{l}19.4 \pm \\
0.8\end{array}$ & $\begin{array}{l}0.46 \pm \\
0.02\end{array}$ & $\begin{array}{l}2.26 \pm \\
0.11\end{array}$ & $\begin{array}{l}0.49 \pm \\
0.02\end{array}$ & $\begin{array}{l}0.36 \pm \\
0.00\end{array}$ & $\begin{array}{l}0.18 \pm \\
0.01\end{array}$ & $\begin{array}{l}0.98 \pm \\
0.03\end{array}$ & $19.9 \pm 1.1$ \\
\hline K2187 & BLW2-14 & 1.33 & $5 \pm 3$ & $37.7 \pm 1.9$ & $\begin{array}{l}1.62 \pm \\
0.08\end{array}$ & $\begin{array}{l}6.20 \pm \\
0.31\end{array}$ & $\begin{array}{l}0.79 \pm \\
0.04\end{array}$ & $\begin{array}{l}0.63 \pm \\
0.00\end{array}$ & $\begin{array}{l}0.18 \pm \\
0.01\end{array}$ & $\begin{array}{l}2.12 \pm \\
0.10\end{array}$ & $17.8 \pm 1.2$ \\
\hline K2188 & BLW2-15 & 1.44 & $5 \pm 3$ & $41.7 \pm 1.7$ & $\begin{array}{l}1.61 \pm \\
0.08\end{array}$ & $\begin{array}{l}6.55 \pm \\
0.33\end{array}$ & $\begin{array}{l}0.84 \pm \\
0.04\end{array}$ & $\begin{array}{l}0.73 \pm \\
0.00\end{array}$ & $\begin{array}{l}0.17 \pm \\
0.01\end{array}$ & $\begin{array}{l}2.21 \pm \\
0.10\end{array}$ & $18.9 \pm 1.2$ \\
\hline K2189 & BLW2-16 & 1.98 & $3 \pm 2$ & $14.3 \pm 0.6$ & $\begin{array}{l}0.34 \pm \\
0.02\end{array}$ & $\begin{array}{l}1.80 \pm \\
0.09\end{array}$ & $\begin{array}{l}0.27 \pm \\
0.01\end{array}$ & $\begin{array}{l}0.25 \pm \\
0.00\end{array}$ & $\begin{array}{l}0.16 \pm \\
0.01\end{array}$ & $\begin{array}{l}0.72 \pm \\
0.03\end{array}$ & $19.9 \pm 1.1$ \\
\hline K2190 & BLW2-17 & 2.70 & $3 \pm 2$ & $11.6 \pm 1.2$ & $\begin{array}{l}0.18 \pm \\
0.01\end{array}$ & $\begin{array}{l}1.38 \pm \\
0.07\end{array}$ & $\begin{array}{l}0.31 \pm \\
0.02\end{array}$ & $\begin{array}{l}0.18 \pm \\
0.00\end{array}$ & $\begin{array}{l}0.15 \pm \\
0.01\end{array}$ & $\begin{array}{l}0.52 \pm \\
0.02\end{array}$ & $22.3 \pm 2.5$ \\
\hline K2191 & BLW2-18 & 1.93 & $3 \pm 2$ & $12.8 \pm 0.5$ & $\begin{array}{l}0.16 \pm \\
0.01\end{array}$ & $\begin{array}{l}1.28 \pm \\
0.06\end{array}$ & $\begin{array}{l}0.30 \pm \\
0.02\end{array}$ & $\begin{array}{l}0.14 \pm \\
0.00\end{array}$ & $\begin{array}{l}0.16 \pm \\
0.01\end{array}$ & $\begin{array}{l}0.48 \pm \\
0.02\end{array}$ & $26.5 \pm 1.4$ \\
\hline K2192 & BLW2-19 & 2.73 & $5 \pm 3$ & $21.7 \pm 0.8$ & $\begin{array}{l}0.37 \pm \\
0.02\end{array}$ & $\begin{array}{l}1.91 \pm \\
0.10\end{array}$ & $\begin{array}{l}0.25 \pm \\
0.01\end{array}$ & $\begin{array}{l}0.34 \pm \\
0.00\end{array}$ & $\begin{array}{l}0.15 \pm \\
0.01\end{array}$ & $\begin{array}{l}0.82 \pm \\
0.03\end{array}$ & $26.6 \pm 1.3$ \\
\hline K2193 & BLW2-20 & 3.13 & $5 \pm 3$ & $11.4 \pm 0.6$ & $\begin{array}{l}0.14 \pm \\
0.01\end{array}$ & $\begin{array}{l}1.19 \pm \\
0.06\end{array}$ & $\begin{array}{l}0.16 \pm \\
0.01\end{array}$ & $\begin{array}{l}0.13 \pm \\
0.00\end{array}$ & $\begin{array}{l}0.14 \pm \\
0.01\end{array}$ & $\begin{array}{l}0.41 \pm \\
0.01\end{array}$ & $27.9 \pm 1.7$ \\
\hline K2194 & BLW2-21 & 3.68 & $3 \pm 2$ & $\begin{array}{l}18.2 \pm \\
0.6\end{array}$ & $\begin{array}{l}0.23 \pm \\
0.01\end{array}$ & $\begin{array}{l}1.37 \pm \\
0.07\end{array}$ & $\begin{array}{l}0.23 \pm \\
0.01\end{array}$ & $\begin{array}{l}0.21 \pm \\
0.00\end{array}$ & $\begin{array}{l}0.13 \pm \\
0.01\end{array}$ & $\begin{array}{l}0.55 \pm \\
0.02\end{array}$ & $33.0 \pm 1.6$ \\
\hline K2196 & BLW2-23 & 3.22 & $3 \pm 2$ & $140 \pm 6$ & $0.23 \pm$ & $1.76 \pm$ & $0.26 \pm$ & $0.26 \pm$ & $0.14 \pm$ & $0.55 \pm$ & $256 \pm 14$ \\
\hline
\end{tabular}




\begin{tabular}{|c|c|c|c|c|c|c|c|c|c|c|c|}
\hline & & & & & 0.01 & 0.09 & 0.01 & 0.00 & 0.01 & 0.02 & \\
\hline K2197 & BLW2-24 & $4 \cdot 51$ & $3 \pm 2$ & $152 \pm 10$ & $\begin{array}{l}0.16 \pm \\
0.01\end{array}$ & $\begin{array}{l}1.30 \pm \\
0.07\end{array}$ & $\begin{array}{l}0.23 \pm \\
0.01\end{array}$ & $\begin{array}{l}0.23 \pm \\
0.00\end{array}$ & $\begin{array}{l}0.12 \pm \\
0.01\end{array}$ & $\begin{array}{l}0.41 \pm \\
0.02\end{array}$ & $369 \pm 27$ \\
\hline K2198 & BLW2-25 & 0.97 & $3 \pm 2$ & $12.9 \pm 0.6$ & $\begin{array}{l}0.20 \pm \\
0.01\end{array}$ & $\begin{array}{l}1.67 \pm \\
0.08\end{array}$ & $\begin{array}{l}0.24 \pm \\
0.01\end{array}$ & $\begin{array}{l}0.24 \pm \\
0.00\end{array}$ & $\begin{array}{l}0.19 \pm \\
0.01\end{array}$ & $\begin{array}{l}0.54 \pm \\
0.02\end{array}$ & $23.7 \pm 1.4$ \\
\hline K2199 & BLW2-26 & 2.17 & $5 \pm 3$ & $12.7 \pm 0.4$ & $\begin{array}{l}0.20 \pm \\
0.01\end{array}$ & $\begin{array}{l}1.36 \pm \\
0.07\end{array}$ & $\begin{array}{l}0.17 \pm \\
0.01\end{array}$ & $\begin{array}{l}0.17 \pm \\
0.00\end{array}$ & $\begin{array}{l}0.16 \pm \\
0.01\end{array}$ & $\begin{array}{l}0.56 \pm \\
0.02\end{array}$ & $22.8 \pm 1.0$ \\
\hline K2200 & BLW2-27 & 3.59 & $5 \pm 3$ & $12.0 \pm 0.5$ & $\begin{array}{l}0.23 \pm \\
0.01\end{array}$ & $\begin{array}{l}1.48 \pm \\
0.07\end{array}$ & $\begin{array}{l}0.21 \pm \\
0.01\end{array}$ & $\begin{array}{l}0.21 \pm \\
0.00\end{array}$ & $\begin{array}{l}0.13 \pm \\
0.01\end{array}$ & $\begin{array}{l}0.57 \pm \\
0.02\end{array}$ & $21.0 \pm 1.1$ \\
\hline K22O1 & BLW2-28 & $5 \cdot 43$ & $3 \pm 2$ & $13.7 \pm 0.4$ & $\begin{array}{l}0.28 \pm \\
0.01\end{array}$ & $\begin{array}{l}1.46 \pm \\
0.07\end{array}$ & $\begin{array}{l}0.24 \pm \\
0.01\end{array}$ & $\begin{array}{l}0.24 \pm \\
0.00\end{array}$ & $\begin{array}{l}0.11 \pm \\
0.01\end{array}$ & $\begin{array}{l}0.53 \pm \\
0.02\end{array}$ & $25.9 \pm 1.3$ \\
\hline \multicolumn{12}{|c|}{ Blowout 3} \\
\hline K22O2 & BLW3-01 & 0.86 & $3 \pm 2$ & $17.1 \pm 0.6$ & $\begin{array}{l}0.39 \pm \\
0.02\end{array}$ & $\begin{array}{l}2.42 \pm \\
0.12\end{array}$ & $\begin{array}{l}0.32 \pm \\
0.02\end{array}$ & $\begin{array}{l}0.39 \pm \\
0.00\end{array}$ & $\begin{array}{l}0.19 \pm \\
0.01\end{array}$ & $\begin{array}{l}0.94 \pm \\
0.03\end{array}$ & $18.3 \pm 0.9$ \\
\hline K2203 & BLW3-02 & 1.17 & $3 \pm 2$ & $17.6 \pm 0.9$ & $\begin{array}{l}0.32 \pm \\
0.02\end{array}$ & $\begin{array}{l}2.07 \pm \\
0.10\end{array}$ & $\begin{array}{l}0.29 \pm \\
0.01\end{array}$ & $\begin{array}{l}0.33 \pm \\
0.00\end{array}$ & $\begin{array}{l}0.18 \pm \\
0.01\end{array}$ & $\begin{array}{l}0.81 \pm \\
0.03\end{array}$ & $21.6 \pm 1.3$ \\
\hline K2204 & BLW3-O3 & 1.43 & $5 \pm 3$ & $11.6 \pm 0.4$ & $\begin{array}{l}0.30 \pm \\
0.02\end{array}$ & $\begin{array}{l}1.86 \pm \\
0.09\end{array}$ & $\begin{array}{l}0.26 \pm \\
0.01\end{array}$ & $\begin{array}{l}0.36 \pm \\
0.00\end{array}$ & $\begin{array}{l}0.17 \pm \\
0.01\end{array}$ & $\begin{array}{l}0.81 \pm \\
0.02\end{array}$ & $14.3 \pm 0.6$ \\
\hline K22O5 & BLW3-04 & 2.25 & $5 \pm 3$ & $\begin{array}{l}25.4 \pm \\
0.9\end{array}$ & $\begin{array}{l}0.62 \pm \\
0.03\end{array}$ & $\begin{array}{l}3.00 \pm \\
0.15\end{array}$ & $\begin{array}{l}0.37 \pm \\
0.02\end{array}$ & $\begin{array}{l}0.25 \pm \\
0.00\end{array}$ & $\begin{array}{l}0.16 \pm \\
0.01\end{array}$ & $\begin{array}{l}0.95 \pm \\
0.04\end{array}$ & $26.8 \pm 1.5$ \\
\hline K2206 & BLW3-O5 & 2.85 & $5 \pm 3$ & $17.0 \pm 1.1$ & $\begin{array}{l}0.23 \pm \\
0.01\end{array}$ & $\begin{array}{l}1.72 \pm \\
0.09\end{array}$ & $\begin{array}{l}0.20 \pm \\
0.01\end{array}$ & $\begin{array}{l}0.38 \pm \\
0.00\end{array}$ & $\begin{array}{l}0.15 \pm \\
0.01\end{array}$ & $\begin{array}{l}0.75 \pm \\
0.02\end{array}$ & $22.8 \pm 1.5$ \\
\hline K2207 & BLW3-06 & $4 \cdot 45$ & $5 \pm 3$ & $19.4 \pm 1.2$ & $\begin{array}{l}0.32 \pm \\
0.02\end{array}$ & $\begin{array}{l}2.17 \pm \\
0.11\end{array}$ & $\begin{array}{l}0.25 \pm \\
0.01\end{array}$ & $\begin{array}{l}0.20 \pm \\
0.00\end{array}$ & $\begin{array}{l}0.12 \pm \\
0.01\end{array}$ & $\begin{array}{l}0.62 \pm \\
0.02\end{array}$ & $31.4 \pm 2.2$ \\
\hline K2208 & BLW3-07 & 2.96 & $5 \pm 3$ & $16.5 \pm 1.1$ & $\begin{array}{l}0.29 \pm \\
0.01\end{array}$ & $\begin{array}{l}1.74 \pm \\
0.09\end{array}$ & $\begin{array}{l}0.24 \pm \\
0.01\end{array}$ & $\begin{array}{l}0.25 \pm \\
0.00\end{array}$ & $\begin{array}{l}0.14 \pm \\
0.01\end{array}$ & $\begin{array}{l}0.65 \pm \\
0.02\end{array}$ & $25.2 \pm 1.8$ \\
\hline K2209 & BLW3-08 & 3.99 & $3 \pm 2$ & $9.7 \pm 0.5$ & $\begin{array}{l}0.09 \pm \\
0.00\end{array}$ & $\begin{array}{l}0.89 \pm \\
0.04\end{array}$ & $\begin{array}{l}0.17 \pm \\
0.01\end{array}$ & $\begin{array}{l}0.17 \pm \\
0.00\end{array}$ & $\begin{array}{l}0.13 \pm \\
0.01\end{array}$ & $\begin{array}{l}0.40 \pm \\
0.01\end{array}$ & $24.5 \pm 1.6$ \\
\hline
\end{tabular}




\begin{tabular}{|c|c|c|c|c|c|c|c|c|c|c|c|}
\hline K2210 & BLW3-09 & 1.08 & $3 \pm 2$ & $13.8 \pm 0.5$ & $\begin{array}{l}0.30 \pm \\
0.01\end{array}$ & $\begin{array}{l}1.95 \pm \\
0.10\end{array}$ & $\begin{array}{l}0.28 \pm \\
0.01\end{array}$ & $\begin{array}{l}0.20 \pm \\
0.00\end{array}$ & $\begin{array}{l}0.18 \pm \\
0.01\end{array}$ & $\begin{array}{l}0.67 \pm \\
0.02\end{array}$ & $\begin{array}{l}20.6 \pm \\
1.0\end{array}$ \\
\hline K2211 & BLW3-10 & 1.55 & $5 \pm 3$ & $16.7 \pm 0.7$ & $\begin{array}{l}0.36 \pm \\
0.02\end{array}$ & $\begin{array}{l}1.83 \pm \\
0.09\end{array}$ & $\begin{array}{l}0.22 \pm \\
0.01\end{array}$ & $\begin{array}{l}0.24 \pm \\
0.00\end{array}$ & $\begin{array}{l}0.17 \pm \\
0.01\end{array}$ & $\begin{array}{l}0.73 \pm \\
0.03\end{array}$ & $22.8 \pm 1.3$ \\
\hline K2212 & BLW3-11 & 2.79 & $5 \pm 3$ & $14.2 \pm 0.6$ & $\begin{array}{l}0.28 \pm \\
0.01\end{array}$ & $\begin{array}{l}1.70 \pm \\
0.09\end{array}$ & $\begin{array}{l}0.23 \pm \\
0.01\end{array}$ & $\begin{array}{l}0.27 \pm \\
0.00\end{array}$ & $\begin{array}{l}0.15 \pm \\
0.01\end{array}$ & $\begin{array}{l}0.67 \pm \\
0.02\end{array}$ & $21.1 \pm 1.1$ \\
\hline K2213 & BLW3-12 & $4 \cdot 30$ & $5 \pm 3$ & $22.6 \pm 1.1$ & $\begin{array}{l}0.78 \pm \\
0.04\end{array}$ & $\begin{array}{l}3.62 \pm \\
0.18\end{array}$ & $\begin{array}{l}0.47 \pm \\
0.02\end{array}$ & $\begin{array}{l}0.42 \pm \\
0.00\end{array}$ & $\begin{array}{l}0.12 \pm \\
0.01\end{array}$ & $\begin{array}{l}1.21 \pm \\
0.05\end{array}$ & $18.7 \pm 1.2$ \\
\hline K2214 & BLW3-13 & 3.46 & $5 \pm 3$ & $20.0 \pm 1.5$ & $\begin{array}{l}0.88 \pm \\
0.04\end{array}$ & $\begin{array}{l}3.14 \pm \\
0.16\end{array}$ & $\begin{array}{l}0.46 \pm \\
0.02\end{array}$ & $\begin{array}{l}0.37 \pm \\
0.00\end{array}$ & $\begin{array}{l}0.14 \pm \\
0.01\end{array}$ & $\begin{array}{l}1.24 \pm \\
0.06\end{array}$ & $16.1 \pm 1.4$ \\
\hline K2215 & BLW3-14 & 5.25 & $5 \pm 3$ & $\begin{array}{l}10.8 \pm \\
0.8\end{array}$ & $\begin{array}{l}0.13 \pm \\
0.01\end{array}$ & $\begin{array}{l}1.22 \pm \\
0.06\end{array}$ & $\begin{array}{l}0.16 \pm \\
0.01\end{array}$ & $\begin{array}{l}0.13 \pm \\
0.00\end{array}$ & $\begin{array}{l}0.11 \pm \\
0.01\end{array}$ & $\begin{array}{l}0.38 \pm \\
0.01\end{array}$ & $\begin{array}{l}28.3 \pm \\
2.4\end{array}$ \\
\hline K2216 & BLW3-15 & 6.37 & $5 \pm 3$ & $13.1 \pm 0.6$ & $\begin{array}{l}0.22 \pm \\
0.01\end{array}$ & $\begin{array}{l}1.21 \pm \\
0.06\end{array}$ & $\begin{array}{l}0.18 \pm \\
0.01\end{array}$ & $\begin{array}{l}0.25 \pm \\
0.00\end{array}$ & $\begin{array}{l}0.10 \pm \\
0.01\end{array}$ & $\begin{array}{l}0.55 \pm \\
0.02\end{array}$ & $23.9 \pm 1.3$ \\
\hline K2217 & BLW3-16 & $7 \cdot 77$ & $3 \pm 2$ & $11.9 \pm 0.5$ & $\begin{array}{l}0.13 \pm \\
0.01\end{array}$ & $\begin{array}{l}0.90 \pm \\
0.05\end{array}$ & $\begin{array}{l}0.17 \pm \\
0.01\end{array}$ & $\begin{array}{l}0.10 \pm \\
0.00\end{array}$ & $\begin{array}{l}0.08 \pm \\
0.01\end{array}$ & $\begin{array}{l}0.31 \pm \\
0.01\end{array}$ & $38.6 \pm 2.1$ \\
\hline K2218 & BLW3-17 & 8.07 & $5 \pm 3$ & $11.9 \pm 0.6$ & $\begin{array}{l}0.24 \pm \\
0.01\end{array}$ & $\begin{array}{l}1.49 \pm \\
0.07\end{array}$ & $\begin{array}{l}0.22 \pm \\
0.01\end{array}$ & $\begin{array}{l}0.26 \pm \\
0.00\end{array}$ & $\begin{array}{l}0.08 \pm \\
0.01\end{array}$ & $\begin{array}{l}0.57 \pm \\
0.02\end{array}$ & $20.9 \pm 1.2$ \\
\hline K2219 & BLW3-18 & 3.48 & $5 \pm 3$ & $\begin{array}{l}0.13 \pm \\
0.02\end{array}$ & $\begin{array}{l}0.22 \pm \\
0.01\end{array}$ & $\begin{array}{l}1.27 \pm \\
0.06\end{array}$ & $\begin{array}{l}0.16 \pm \\
0.01\end{array}$ & $\begin{array}{l}0.18 \pm \\
0.00\end{array}$ & $\begin{array}{l}0.13 \pm \\
0.01\end{array}$ & $\begin{array}{l}0.51 \pm \\
0.02\end{array}$ & $\begin{array}{l}0.25 \pm \\
0.04\end{array}$ \\
\hline K2220 & BLW3-19 & 1.06 & $5 \pm 3$ & $8.3 \pm 0.5$ & $\begin{array}{l}0.31 \pm \\
0.02\end{array}$ & $\begin{array}{l}1.87 \pm \\
0.09\end{array}$ & $\begin{array}{l}0.21 \pm \\
0.01\end{array}$ & $\begin{array}{l}0.20 \pm \\
0.00\end{array}$ & $\begin{array}{l}0.18 \pm \\
0.01\end{array}$ & $\begin{array}{l}0.66 \pm \\
0.02\end{array}$ & $12.6 \pm 0.9$ \\
\hline K2221 & BLW3-20 & 1.41 & $5 \pm 3$ & $12.3 \pm 0.4$ & $\begin{array}{l}0.24 \pm \\
0.01\end{array}$ & $\begin{array}{l}1.38 \pm \\
0.07\end{array}$ & $\begin{array}{l}0.17 \pm \\
0.01\end{array}$ & $\begin{array}{l}0.23 \pm \\
0.00\end{array}$ & $\begin{array}{l}0.17 \pm \\
0.01\end{array}$ & $\begin{array}{l}0.62 \pm \\
0.02\end{array}$ & $19.9 \pm 0.9$ \\
\hline K2222 & BLW3-21 & 3.03 & $5 \pm 3$ & $15.7 \pm 1.5$ & $\begin{array}{l}0.25 \pm \\
0.01\end{array}$ & $\begin{array}{l}1.83 \pm \\
0.09\end{array}$ & $\begin{array}{l}0.22 \pm \\
0.01\end{array}$ & $\begin{array}{l}0.26 \pm \\
0.00\end{array}$ & $\begin{array}{l}0.14 \pm \\
0.01\end{array}$ & $\begin{array}{l}0.64 \pm \\
0.02\end{array}$ & $24.5 \pm 2.5$ \\
\hline K2223 & BLW3-22 & 3.54 & $5 \pm 3$ & $13.8 \pm 0.9$ & $\begin{array}{l}0.32 \pm \\
0.02\end{array}$ & $\begin{array}{l}1.99 \pm \\
0.10\end{array}$ & $\begin{array}{l}0.23 \pm \\
0.01\end{array}$ & $\begin{array}{l}0.28 \pm \\
0.00\end{array}$ & $\begin{array}{l}0.13 \pm \\
0.01\end{array}$ & $\begin{array}{l}0.71 \pm \\
0.02\end{array}$ & $19.5 \pm 1.5$ \\
\hline
\end{tabular}


K2224

BLW3-23 4.29

$5 \pm 3$

$13.5 \pm 0.5 \quad 0.27 \pm$

$1.66 \pm$

$0.20 \pm$

$0.27 \pm$

$0.12 \pm$

$0.64 \pm$

0.02

$21.0 \pm 1.0$

Blowout 4

\begin{tabular}{|c|c|c|c|c|c|c|c|c|c|c|c|}
\hline K2225 & BLW4-O1 & 0.45 & $5 \pm 3$ & $\begin{array}{l}0.10 \pm \\
0.01\end{array}$ & $\begin{array}{l}0.41 \pm \\
0.02\end{array}$ & $\begin{array}{l}2.15 \pm \\
0.11\end{array}$ & $\begin{array}{l}0.22 \pm \\
0.01\end{array}$ & $\begin{array}{l}0.31 \pm \\
0.00\end{array}$ & $\begin{array}{l}0.20 \pm \\
0.02\end{array}$ & $\begin{array}{l}0.86 \pm \\
0.03\end{array}$ & $\begin{array}{l}0.12 \pm \\
0.01\end{array}$ \\
\hline K2226 & BLW4-02 & 1.12 & $5 \pm 3$ & $\begin{array}{l}0.16 \pm \\
0.03\end{array}$ & $\begin{array}{l}0.50 \pm \\
0.02\end{array}$ & $\begin{array}{l}2.35 \pm \\
0.12\end{array}$ & $\begin{array}{l}0.24 \pm \\
0.01\end{array}$ & $\begin{array}{l}0.33 \pm \\
0.00\end{array}$ & $\begin{array}{l}0.18 \pm \\
0.01\end{array}$ & $\begin{array}{l}0.93 \pm \\
0.03\end{array}$ & $\begin{array}{l}0.17 \pm \\
0.03\end{array}$ \\
\hline
\end{tabular}

Linear dune

\begin{tabular}{|c|c|c|c|c|c|c|c|c|c|c|c|}
\hline K2227 & MSH-O1 & 0.38 & $5 \pm 3$ & $\begin{array}{l}1.20 \pm \\
0.12\end{array}$ & $\begin{array}{l}0.18 \pm \\
0.01\end{array}$ & $\begin{array}{l}1.46 \pm \\
0.07\end{array}$ & $\begin{array}{l}0.16 \pm \\
0.01\end{array}$ & $\begin{array}{l}0.09 \pm \\
0.00\end{array}$ & $\begin{array}{l}0.20 \pm \\
0.02\end{array}$ & $\begin{array}{l}0.46 \pm \\
0.02\end{array}$ & $2.6 \pm 0.3$ \\
\hline K2228 & MSH-O2 & 0.82 & $5 \pm 3$ & $\begin{array}{l}6.5 \pm \\
0.52\end{array}$ & $\begin{array}{l}0.18 \pm \\
0.01\end{array}$ & $\begin{array}{l}1.48 \pm \\
0.07\end{array}$ & $\begin{array}{l}0.20 \pm \\
0.01\end{array}$ & $\begin{array}{l}0.09 \pm \\
0.00\end{array}$ & $\begin{array}{l}0.19 \pm \\
0.02\end{array}$ & $\begin{array}{l}0.46 \pm \\
0.02\end{array}$ & $14.0 \pm 1.3$ \\
\hline K2229 & MSH-O3 & 1.27 & $5 \pm 3$ & $9.6 \pm 1.12$ & $\begin{array}{l}0.18 \pm \\
0.01\end{array}$ & $\begin{array}{l}1.58 \pm \\
0.08\end{array}$ & $\begin{array}{l}0.19 \pm \\
0.01\end{array}$ & $\begin{array}{l}0.10 \pm \\
0.00\end{array}$ & $\begin{array}{l}0.18 \pm \\
0.01\end{array}$ & $\begin{array}{l}0.46 \pm \\
0.02\end{array}$ & $21.0 \pm 2.6$ \\
\hline K2230 & MSH-O4 & 1.95 & $5 \pm 3$ & $\begin{array}{l}13.3 \pm \\
0.66\end{array}$ & $\begin{array}{l}0.18 \pm \\
0.01\end{array}$ & $\begin{array}{l}1.53 \pm \\
0.08\end{array}$ & $\begin{array}{l}0.20 \pm \\
0.01\end{array}$ & $\begin{array}{l}0.10 \pm \\
0.00\end{array}$ & $\begin{array}{l}0.16 \pm \\
0.01\end{array}$ & $\begin{array}{l}0.44 \pm \\
0.02\end{array}$ & $\begin{array}{l}30.0 \pm \\
1.9\end{array}$ \\
\hline
\end{tabular}

